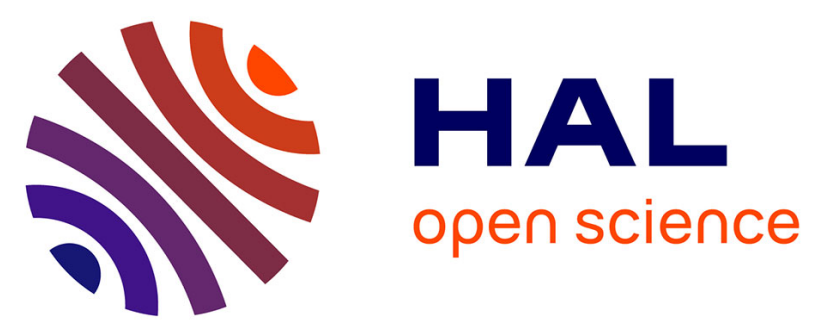

\title{
Fungal and plant gene expression in the Tulasnella calospora-Serapias vomeracea symbiosis provides clues about nitrogen pathways in orchid mycorrhizas
}

Valeria Fochi, Walter Chitarra, Annegret Kohler, Samuele Voyron, Vasanth R Singan, Erika A Lindquist, Kerrie W Barry, Mariangela Girlanda, Igor V

Grigoriev, Francis Martin, et al.

\section{To cite this version:}

Valeria Fochi, Walter Chitarra, Annegret Kohler, Samuele Voyron, Vasanth R Singan, et al.. Fungal and plant gene expression in the Tulasnella calospora-Serapias vomeracea symbiosis provides clues about nitrogen pathways in orchid mycorrhizas. New Phytologist, 2017, 213 (1), pp.365-379. 10.1111/nph.14279 . hal-01493087

\section{HAL Id: hal-01493087 \\ https://hal.science/hal-01493087}

Submitted on 20 Mar 2017

HAL is a multi-disciplinary open access archive for the deposit and dissemination of scientific research documents, whether they are published or not. The documents may come from teaching and research institutions in France or abroad, or from public or private research centers.
L'archive ouverte pluridisciplinaire HAL, est destinée au dépôt et à la diffusion de documents scientifiques de niveau recherche, publiés ou non, émanant des établissements d'enseignement et de recherche français ou étrangers, des laboratoires publics ou privés.

\section{다(1)(2)}

Distributed under a Creative Commons Attribution - ShareAlikel 4.0 International 


\title{
Fungal and plant gene expression in the Tulasnella calospora-Serapias vomeracea symbiosis provides clues about nitrogen pathways in orchid mycorrhizas
}

\author{
Valeria Fochi $^{1,2}$, Walter Chitarra ${ }^{2}$, Annegret Kohler ${ }^{3}$, Samuele Voyron ${ }^{1}$, Vasanth R. Singan ${ }^{4}$, Erika A. Lindquist ${ }^{4}$, \\ Kerrie W. Barry ${ }^{4}$, Mariangela Girlanda ${ }^{1,2}$, Igor V. Grigoriev ${ }^{4}$, Francis Martin ${ }^{3}$, Raffaella Balestrini ${ }^{2}$ and Silvia \\ Perotto $^{1,2}$
}

${ }^{1}$ Department of Life Sciences and Systems Biology, University of Turin, 10125 Turin, Italy; ${ }^{2}$ Institute for Sustainable Plant Protection (IPSP)-CNR, 10125 Turin, Italy; ${ }^{3}$ Lab of Excellence

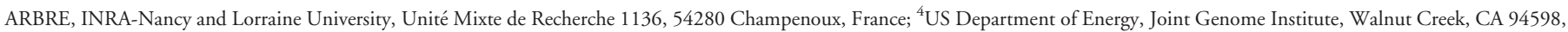
USA

Authors for correspondence:

Silvia Perotto

Tel: +390116705987

Email: silvia.perotto@unito.it

Raffaella Balestrini

Tel: +390116502927

Email: raffaella.balestrini@ipsp.cnr.it

Received: 6 July 2016

Accepted: 19 September 2016

New Phytologist (2017) 213: 365-379

doi: 10.1111/nph.14279

Key words: ammonium transporters, gene expression, nitrogen $(\mathrm{N})$, orchid mycorrhiza, Serapias, transcriptomics, Tulasnella.

\section{Summary}

- Orchids are highly dependent on their mycorrhizal fungal partners for nutrient supply, especially during early developmental stages. In addition to organic carbon, nitrogen $(\mathrm{N})$ is probably a major nutrient transferred to the plant because orchid tissues are highly $\mathrm{N}$-enriched. We know almost nothing about the $\mathrm{N}$ form preferentially transferred to the plant or about the key molecular determinants required for $\mathrm{N}$ uptake and transfer.

- We identified, in the genome of the orchid mycorrhizal fungus Tulasnella calospora, two functional ammonium transporters and several amino acid transporters but found no evidence of a nitrate assimilation system, in agreement with the $\mathrm{N}$ preference of the free-living mycelium grown on different $\mathrm{N}$ sources.

- Differential expression in symbiosis of a repertoire of fungal and plant genes involved in the transport and metabolism of $\mathrm{N}$ compounds suggested that organic $\mathrm{N}$ may be the main form transferred to the orchid host and that ammonium is taken up by the intracellular fungus from the apoplatic symbiotic interface.

- This is the first study addressing the genetic determinants of $N$ uptake and transport in orchid mycorrhizas, and provides a model for nutrient exchanges at the symbiotic interface, which may guide future experiments.

\section{Introduction}

Like the majority of terrestrial plants, orchids form mycorrhizal associations with soil fungi that provide them with essential nutrients. However, orchids are peculiar because seed germination and early development in nature fully depend on the mycobionts (Rasmussen, 1995; Smith \& Read, 2008), which provide the embryo with organic carbon $(\mathrm{C})$ and other essential nutrients. Following seed germination, orchids form the protocorm, a heterotrophic structure that precedes seedling development, and continue to rely on the mycobiont for organic $\mathrm{C}$ supply, a strategy known as mycoheterotrophy (Leake, 2004). Some orchid species remain achlorophyllous or with inefficient photosynthesis at adulthood (Selosse \& Roy, 2009; Hynson et al., 2013), whereas most orchids develop photosynthetic leaves and become fully autotrophic. These photosynthetic orchid species usually associate with saprotrophic fungi belonging to the anamorphic form-genus Rhizoctonia, featuring basidiomycete members in the Ceratobasidiaceae, Tulasnellaceae and Sebacinales (Taylor et al., 2002; Weiß et al., 2004).
Given the fascinating mycoheterotrophic strategy of orchids, most experiments on nutrient transfer in orchid mycorrhizas have focussed on the acquisition and transfer of organic $\mathrm{C}$, whereas little is known about other nutrients, such as nitrogen $(\mathrm{N}) . \mathrm{N}$ is often a limiting factor for plant growth in natural ecosystems (Vitousek \& Howarth, 1991). Particularly high concentrations of total $\mathrm{N}$ have been reported in the tissues of many orchids (see Hynson et al., 2013) and measurements of stable isotope natural abundance, commonly used to identify the source and direction of nutrient flow in ecological systems (Dawson etal., 2002), provide evidence that terrestrial orchids receive $\mathrm{N}$ from their mycobionts (Gebauer \& Meyer, 2003; Hynson etal., 2013; Stöckel et al., 2014).

Nitrogen occurs in the soil in inorganic forms, such as ammonium $\left(\mathrm{NH}_{4}^{+}\right)$and nitrate $\left(\mathrm{NO}_{3}{ }^{-}\right)$, or in organic $\mathrm{N}$ compounds. Fungal uptake and transfer of soil-derived $\mathrm{N}$ to host plants has been extensively investigated in arbuscular mycorrhizal (AM) and ectomycorrhizal (ECM) fungi (see references in Chalot et al., 2006; Martin etal., 2007; Müller etal., 2007; Koegel etal., 2015; Bücking \& Kafle, 2015). Nitrate transporters and genes 
responsible for nitrate utilization have been identified mainly in AM fungi (Kaldorf et al., 1998; Tian etal., 2010; Koegel et al., 2015), and nitrophilous ECM fungi (Plassard et al., 2000; Jargeat et al., 2003; Montanini et al., 2006). Genes coding for high- and low-affinity ammonium transporters have been identified and characterized in both AM (López-Pedrosa et al., 2006; PérezTienda etal., 2011; Calabrese etal., 2016) and ECM fungi (Javelle etal., 2001; Montanini etal., 2002; Willmann etal., 2007). Amino acid permeases and peptide transporters, which allow for organic $\mathrm{N}$ uptake, have been identified and characterized mainly in ECM fungi (Nehls et al., 1999; Wipf et al., 2002; Guidot et al., 2005; Benjdia etal., 2006; Shah et al., 2013) but also in AM fungi (Cappellazzo et al., 2008; Belmondo et al., 2014), although the ability of AM fungi to utilize organic $\mathrm{N}$ sources is considered to be relatively low. Ammonium is thought to be the main $\mathrm{N}$ form transferred to the host plant in AM (Bücking \& Kafle, 2015; Koegel et al., 2015), whereas N transfer across the ECM interface is not completely clear and may involve both organic (i.e. amino acids) and inorganic $\mathrm{N}$ forms (Chalot et al., 2006; Couturier et al., 2007; Müller et al., 2007).

Compared with ECM and AM symbiosis, very little is known about $\mathrm{N}$ metabolism in orchid mycorrhizas. Some orchid mycorrhizal fungi belonging to Ceratobasidium, Tulasnella and Sebacina can grow on organic $\mathrm{N}$ as well as on ammonium (Hadley \& Ong, 1978; Nurfadilah etal., 2013), and a Ceratobasidium spp. isolate also grew on nitrate (Nurfadilah etal., 2013). Uptake of $\mathrm{N}$ from inorganic sources by a Ceratobasidium isolate and transfer to the host protocorm was demonstrated by Kuga et al. (2014) after feeding the fungus with ${ }^{15} \mathrm{~N}$-labelled $\mathrm{NH}_{4} \mathrm{NO}_{3}$. Cameron et al. (2006) demonstrated uptake of double-labelled $\left[{ }^{13} \mathrm{C}-{ }^{15} \mathrm{~N}\right]$ glycine by Ceratobasidium cornigerum and transfer of labelled ${ }^{15} \mathrm{~N}$ to the adult photosynthetic host Goodyera repens. However, the mechanisms underlying fungal $\mathrm{N}$ uptake and transfer to the plant, as well as the form of $\mathrm{N}$ transferred to the orchid host, remain largely unknown. In the colonized protocorm cells, orchid mycorrhizal fungi form coiled hyphae, known as pelotons (Smith \& Read, 2008), surrounded by a plant-derived membrane and by an apoplastic plant-fungus interface (Peterson et al., 1996). Similarly to the AM arbuscules, fungal pelotons in orchid mycorrhizas are ephemeral structures rhythmically digested inside the host cell (Smith \& Read, 2008). Based on this observation, Rasmussen (1995) proposed fungal lysis as the main mechanism underlying nutrient transfer in orchid mycorrhizas. Although this mechanism may explain some of the nutrient uptake by the plant (Kuga et al., 2014), other authors (see in Smith \& Read, 2008; Cameron etal., 2006, 2008; Kuga et al., 2014) have provided convincing evidence that nutrient transfer takes place across intact membranes.

Here, we used the orchid mycorrhizal fungus Tulasnella calospora isolate AL13/4D, either as free-living mycelium or in symbiosis with achlorophyllous protocorms of the photosynthetic orchid Serapias vomeracea, as a model system to explore the genetic bases of $\mathrm{N}$ uptake and transfer to the mycorrhizal orchid host. In particular, we investigated some fungal genes that may be involved in the uptake of inorganic and organic $\mathrm{N}$ forms and their transfer to the host plant. To this purpose, we used available genomic information as well as RNA-sequencing (RNA-Seq) experiments that compared fungal gene expression on two $\mathrm{N}$ sources (ammonium and glutamine) and/or in symbiosis. We show that T. calospora lacks a nitrate uptake system but has two functional ammonium transporters ( $T$. calospora ammonium transporters 1 and 2, named TcAMT1 and TcAMT2) that were characterized by functional complementation in yeast. The expression pattern of these fungal AMTs, together with the expression of additional T. calospora and S. vomeracea genes potentially involved in $\mathrm{N}$ uptake and transfer, allowed us to formulate hypotheses regarding the $\mathrm{N}$ pathway in orchid mycorrhizas.

\section{Materials and Methods}

\section{Growth of the free-living mycelium}

Tulasnella calospora (Boud.) Juel AL13/4D was isolated from mycorrhizal roots of Anacamptis laxiflora (Lam.) R.M. Bateman, Pridgeon and M.W. Chase in northern Italy (Girlanda et al., 2011) and deposited in the mycological collection of the University of Turin (accession number MUT4182). Free-living mycelium was maintained on solid $2 \%$ malt extract agar at $25^{\circ} \mathrm{C}$. To evaluate growth on different $\mathrm{N}$ sources, eight hyphal plugs (6 mm diameter) of 20-d-old T. calospora mycelia were transferred into flasks containing $50 \mathrm{ml}$ of modified synthetic Pachlewski P5 liquid medium adjusted to $\mathrm{pH} 5.5$ (Kemppainen \& Pardo, 2011) with L-glutamine, monosodium glutamate, ammonium tartrate, sodium nitrate or ammonium sulphate, each added as $0.49 \mathrm{~g}$ of $\mathrm{N}$. Inoculated flasks were maintained at $25^{\circ} \mathrm{C}$ under constant shaking $(120 \mathrm{rpm})$. After $20 \mathrm{~d}$, the mycelium was recovered by filtration, washed with distilled water, weighed and dried to measure biomass. The $\mathrm{pH}$ of the culture medium was measured. Three replicate flasks were used for each $\mathrm{N}$ source.

Modified P5 solid medium with the same $\mathrm{N}$ sources, as well as oat agar medium $(0.3 \%$ milled oats and $1 \%$ agar), were used to grow free-living mycelium for RNA extraction and expression studies. In this case, T. calospora was inoculated onto a sterilized cellophane membrane placed on top of the agar medium (Schumann et al., 2013) and kept until the plate was fully colonized (c. $20 \mathrm{~d}$ ). The mycelium was then collected from the cellophane membrane, immediately frozen in liquid $\mathrm{N}$ and stored at $-80^{\circ} \mathrm{C}$.

\section{Symbiotic and asymbiotic germination of Serapias vomeracea seeds}

Symbiotic germination was obtained by co-inoculation of mycorrhizal fungi and orchid seeds in 9-cm Petri dishes, as described in Ercole et al. (2013). Seeds of Serapias vomeracea (Burm.f.) Briq. were surface-sterilized in $1 \%$ sodium hypochlorite and $0.1 \%$ Tween-20 for $20 \mathrm{~min}$ on a vortex, followed by three 5 -min rinses in sterile distilled water. Seeds were resuspended in sterile water and dropped on strips of autoclaved filter paper $(1.5 \times 3 \mathrm{~cm})$ positioned on solid oat medium ( $0.3 \%$ milled oats and $1 \%$ agar $)$. Plates were inoculated with a plug of actively growing T. calospora mycelium and were incubated at $20^{\circ} \mathrm{C}$ in darkness. 
Asymbiotic seed germination was obtained on modified BM1 culture medium (Van Waes \& Deberg, 1986) at $20^{\circ} \mathrm{C}$ in darkness. Symbiotic and asymbiotic achlorophyllous protocorms collected at stage P2 (Otero etal., 2004) were either frozen immediately in liquid $\mathrm{N}$ and stored at $-80^{\circ} \mathrm{C}$ for RNA extraction, or fixed and embedded in paraffin for laser microdissection or in resin for microscopy.

\section{Gene identification and phylogenetic analysis}

Fungal genes coding for proteins possibly involved in $\mathrm{N}$ uptake and transfer were identified in the T. calospora genome database on the Joint Genome Institute (JGI) fungal genome portal MycoCosm (http://genome.jgi.doe.gov/Tulca1/Tulca1.home.htm). Plant transcripts coding for proteins potentially involved in $\mathrm{N}$ uptake and transfer were selected from the RNA-Seq database obtained in this study, as described in RNA-Seq experiments. Multiple protein alignments were performed with MUSCLE (Edgar, 2004). Phylogenetic trees were constructed with the maximum likelihood method using MEGA v.7.0 (Kumar et al., 2016); bootstrap analyses were conducted on the basis of 1000 resamplings of the sequence alignment.

\section{Full-length TCAMT1 and TCAMT2 isolation}

TcAMT1 (1467 bp) and TcAMT2 (1611 bp) full-length cDNA isolation was carried out through PCR amplification of T. calospora or mycorrhizal S. vomeracea protocorm cDNA with the full-length primers reported in Supporting Information Table S1. PCR reactions were performed in a $50-\mu$ l final volume containing $10 \mu \mathrm{l}$ of $5 \times$ Phusion HF Buffer, $1 \mu \mathrm{l}$ of dNTPs (10 mM stock each), $1.5 \mu \mathrm{l}$ of each primer (10 mM stock), $0.5 \mu \mathrm{l}$ of Phusion High-Fidelity DNA polymerase (New England Biolabs, Hitchin, UK), $34.5 \mu \mathrm{l}$ of water and $1 \mu \mathrm{l}$ of cDNA. PCR amplifications were carried out in a thermal cycler (Biometra $\mathrm{GmbH}$, Göttingen, Germany) using the following programme: $98^{\circ} \mathrm{C}$ for $60 \mathrm{~s} ; 35$ cycles of $98^{\circ} \mathrm{C}$ for $10 \mathrm{~s}, 57^{\circ} \mathrm{C}$ for $10 \mathrm{~s}$ and $72^{\circ} \mathrm{C}$ for $90 \mathrm{~s} ; 72^{\circ} \mathrm{C}$ for $10 \mathrm{~min}$. Amplicons were visualized on $1.2 \%$ agarose gels after electrophoresis in $0.5 \times$ Tris-acetate-EDTA (TAE) buffer, excised from the agarose gel and purified using the Wizard ${ }^{\circledR}$ SV Gel (Promega Corp., Madison, WI, USA) and PCR Clean-Up System (Promega) following the manufacturer's instructions. The purified DNA was eluted in $30 \mu \mathrm{l}$ of nucleasefree water and inserted into the p-GEM T plasmid (Promega) using a T4 DNA Ligase (Promega). Plasmids were transformed into Escherichia coli chemically competent cells (Top10 cells; Invitrogen). Plasmids were then purified, from positive colonies, using the QIAprep Spin Miniprep Kit (Qiagen, Valencia, CA, USA). Sequencing was performed by the sequencing service at Munich University (Sequencing Server, Biocenter of the LMU Munich, Germany).

\section{Heterologous expression of TCAMT1 and TCAMT2 in yeast}

Full-length TcAMT1 and TcAMT2 cDNAs were cloned into the yeast expression vector pFL61 under the control of the constitutive yeast phosphoglycerate kinase (PGK) promoter (Minet etal., 1992). The Saccharomyces cerevisiae triple ammonium permease (mep) mutant 31019b ( $\Delta \Delta \Delta$ mep1;2;3; Marini et al., 1997), kindly provided by Nuria Ferrol (CSIC, Granada, Spain), was transformed with the empty pFL61 vector (negative control) or with the pFL61-TcAMT1 and pFL61AMT2 constructs according to Gietz \& Schiestl (2007). The coding sequence of GintAMT1, characterized in the AM fungus Rhizophagus irregularis (previously Glomus intraradices; LópezPedrosa et al., 2006), was used as a positive control. Transformed yeasts were selected on solid $\mathrm{N}$-free medium ( $2 \%$ agar, $0.17 \%$ yeast nitrogen base without amino acids, and ammonium sulphate) supplemented with $3 \%$ glucose and $0.1 \%$ arginine as the sole $\mathrm{N}$ source, buffered to $\mathrm{pH} 6.1$ with $50 \mathrm{mM}$ MES/Tris (Pérez-Tienda et al., 2011). For growth assays, yeast transformants were grown in liquid $\mathrm{N}$-free medium plus arginine until the optical density at $600 \mathrm{~nm}\left(\mathrm{OD}_{600}\right)$ reached 0.6-0.8. Cells were harvested, washed twice, and resuspended in water to a final $\mathrm{OD}_{600}$ of 2 , and $10-\mu \mathrm{l}$ drops corresponding to a serial 10 -fold dilution were spotted on solid $\mathrm{N}$-free medium supplemented with different $\mathrm{NH}_{4} \mathrm{Cl}$ concentrations as the sole $\mathrm{N}$ source $(0.1$, $0.5,1$ and $5 \mathrm{mM}$ ). Yeast cells were also spotted on $1 \mathrm{mM}$ $\mathrm{NH}_{4} \mathrm{Cl}$-supplemented medium buffered at different $\mathrm{pHs}$ (4.5, 5.5, 6.5 and 7.5) with $50 \mathrm{mM}$ Mes/Tris. Pictures of the plates were taken after $3 \mathrm{~d}$ of incubation at $30^{\circ} \mathrm{C}$.

\section{RNA-Seq experiment}

Two different RNA-Seq experiments were carried out to investigate expression of T. calospora and S. vomeracea genes, and the experimental set-up is illustrated in Fig. S1. In the first experiment (RNA-Seq-A), T. calospora transcripts were investigated in free-living mycelium and in mycorrhizal S. vomeracea protocorms grown on solid oat medium ( $0.3 \%$ milled oats and $1 \%$ agar). Preparation of libraries and $2 \times 100$ bp Illumina HiSeq2000 (Illumina Inc., San Diego, CA, USA) mRNA sequencing (RNASeq) was performed at the IGA Technology Services facilities (Udine, Italy). The complete series has been deposited in NCBI's Gene Expression Omnibus and are accessible through GEO Series accession number GSE63869. For the second experiment (RNA-Seq-B), T. calospora free-living mycelium was grown on modified Melin-Norkrans medium with two different $\mathrm{N}$ sources, ammonium and glutamine, each added as $0.49 \mathrm{~g}$ of $\mathrm{N}$. To investigate fungal and plant gene expression in symbiosis, RNA was also extracted in a parallel experiment from symbiotic and asymbiotic $S$. vomeracea protocorms obtained as described in the 'Symbiotic and asymbiotic germination of Serapias vomeracea seeds' section. Illumina HiSEq2500 sequencing $(2 \times 150 \mathrm{bp})$ was performed at the JGI (Walnut Creek, USA). The complete series of fungal and plant transcripts was submitted to GEO (GSE86968 and GSE87120, respectively). For both RNA-Seq experiments, three separate libraries were prepared from three biological replicates for each condition.

Filtered fastq files of plant-only samples were used as input for de novo assembly of S. vomeracea RNA contigs (Fig. S1). Reads were assembled into consensus sequences using TRINITY (ver. 
2.1.1) (Grabherr et al., 2011). Contigs were annotated following BLASTX searches against the Arabidopsis thaliana (TAIR) and the Phalaenopsis equestris (Cai et al., 2015) proteome.

Reads were aligned either to the T.calospora reference transcripts (http://genome.jgi-psf.org) or to the S. vomeracea de novo assembly using CLC Genomics Workbench (Qiagen Bioinformatics; http://www.qiagenbioinformatics.com/products/ clc-genomics-workbench/). For mapping, the minimum length fraction was 0.9 , the minimum similarity fraction was 0.8 and the maximum number of hits for a read was set to 10 . The unique and total mapped read numbers for each transcript were determined, and then normalized to reads per kilobase of exon model per million mapped reads (RPKM). The Baggerly test (Baggerly et al., 2003) implemented in the CLC Genomic workbench compares the proportions of counts in a group of samples against those of another group of samples and was applied to the data. In addition, Benjamini \& Hochberg multiple-hypothesis testing corrections with false discovery rate (FDR) were used. In our analysis, transcripts were considered to be up-regulated when the fold-change (FC) was $\geq 2.5$ and the FDR was $<0.05$, and down-regulated when the $\mathrm{FC}$ was $\leq 0.5$ and the FDR was $<0.05$.

\section{Real-time quantitative PCR analyses}

Total RNA for quantitative real-time polymerase chain reaction (qPCR) was extracted from symbiotic and asymbiotic S. vomeracea protocorms and from T.calospora free-living mycelia following the method of Chang et al. (1993). Genomic DNA was removed using the Turbo DNA-free ${ }^{\mathrm{TM}}$ reagent (Ambion, Austin, TX, USA), according to the manufacturer's instructions. RNA was then quantified using spectrophotometry (NanoDrop 1000; BioRad) and subjected to a reverse transcription-PCR reaction (RT-PCR) to exclude DNA contamination, using the One Step RT-PCR kit (Qiagen), before cDNA synthesis. SuperScriptII Reverse Transcriptase (Invitrogen) was used to synthesize cDNA starting from 500 ng of total RNA for each sample, following the manufacturer's instructions. At the end of the reaction, cDNA was diluted 1:5 for quantitative gene expression analysis by qPCR. Primers for RT-qPCR (Table S1) were designed using Primer3Plus (http://www.bioin formatics.nl/cgi-bin/primer3plus/primer3plus.cgi/) and tested for their specificity with PRIMER BLAST (http://www.ncbi. nlm.nih.gov/tools/primer-blast/). Reactions were carried out in a StepOnePlus ${ }^{\mathrm{TM}}$ RT-qPCR System (Applied Biosystems, Thermo Fisher Scientific Inc., Waltham, MA, USA), following the SYBR Green method (Power SYBR ${ }^{\circledR}$ Green PCR Master Mix; Applied Biosystems) as described by Perrone et al. (2012). Thermal cycling conditions were as follows: initial denaturation phase at $95^{\circ} \mathrm{C}$ for $10 \mathrm{~min}$, followed by 40 cycles at $95^{\circ} \mathrm{C}$ for $15 \mathrm{~s}$ and $60^{\circ} \mathrm{C}$ for $1 \mathrm{~min}$. Expression of target transcripts was quantified after normalization to the geometric mean of the endogenous control genes, the elongation factor (EF) genes $T c E F-1 \alpha$ and $S v E F-1 \alpha$. Gene expression data were calculated as expression ratios (quantity relative to that of control). All reactions were performed with three biological and three technical replicates.

\section{Laser microdissection analysis}

Symbiotic and asymbiotic S. vomeracea protocorms were collected in RNase-free tubes containing freshly prepared Farmer's fixative (absolute ethanol: glacial acetic acid, 3:1). Samples were dehydrated and embedded in paraffin as described in Pérez-Tienda etal. (2011). Sections $(12 \mu \mathrm{m})$ were cut with a rotary microtome and transferred onto Leica RNase-free PEN foil slides (Leica Microsystems Inc., Bensheim, Germany), dried at $40^{\circ} \mathrm{C}$ in a warming plate, stored at $4^{\circ} \mathrm{C}$ and used within $1 \mathrm{~d}$. Specific cell types were collected from paraffin sections of $S$. vomeracea symbiotic protocorms with a Leica LMD 6500 system (Leica Microsystem), as described by Balestrini et al. (2007). Approximately 10001500 cells for each type were collected, with three independent biological replicates. RNA was extracted from laser microdissected cells following the Pico Pure kit (Life Technologies, Carlsbad, CA, USA) protocol, with some modifications. In particular, DNase treatment was not performed on the kit column, but RNA was treated with Turbo DNAfree (Ambion, Austin, TX, USA), according to the manufacturer's instructions.

The One Step RT-PCR kit (Qiagen) was used to amplify transcripts from three biological replicates. Samples were incubated for $30 \mathrm{~min}$ at $50^{\circ} \mathrm{C}$, followed by $15 \mathrm{~min}$ of incubation at $95^{\circ} \mathrm{C}$. Amplification reactions were run for 40 cycles at $94^{\circ} \mathrm{C}$ for $30 \mathrm{~s}$, $60^{\circ} \mathrm{C}$ for $30 \mathrm{~s}$, and $72^{\circ} \mathrm{C}$ for $40 \mathrm{~s}$ using the same T. calospora and S. vomeracea specific primers used for RT-qPCR (Table S1). DNA contamination in the RNA samples was evaluated with primers for the plant $(S v E F 1 \alpha)$ and the fungal $(T c E F 1 \alpha)$ EF by omitting the RT step at $50^{\circ} \mathrm{C}$ (Fig. S2). PCR products were separated on a $1.4 \%$ agarose gel.

\section{Microscopy}

Symbiotic S. vomeracea protocorms were fixed in $2.5 \%$ $(\mathrm{v} / \mathrm{v})$ glutaraldehyde, post-fixed in $1 \%(\mathrm{w} / \mathrm{v})$ osmium tetroxide and embedded in LR White resin (Polysciences, Warrington, PA, USA) as described in Perotto etal. (2014). Semi-thin sections $(1 \mu \mathrm{m})$ were stained with $1 \%$ $(\mathrm{w} / \mathrm{v})$ toluidine blue for morphological observations. Thin sections $(0.05-0.07 \mu \mathrm{m})$ were post-stained with uranyl acetate and lead citrate before being observed under a Philips CM10 transmission electron microscope (Philips, Eindhoven, the Netherlands).

\section{Statistical analyses}

Significant differences among treatments (T. calospora biomass and RT-qPCR experiments) were tested by a one-way analyses of variance (ANOVA), and Tukey's honest significant difference (HSD) test was used for mean separation when ANOVA results were significant $(P<0.05)$. Significant differences in pairwise comparisons were assessed by Student's t-test. The SPSS statistical software package (v.23.0; SPSS Inc., Cary, NC, USA) was used to run statistical analyses. 


\section{Results}

\section{Growth of Tulasnella calospora on different $\mathrm{N}$ sources}

After $20 \mathrm{~d}$ of culture on modified Pachlewski P5 medium containing some defined organic and inorganic $\mathrm{N}$ sources, the highest fungal biomass (as dry weight) was on glutamine and the lowest on nitrate (Fig. 1). Growth was intermediate on glutamate and ammonium tartrate and slightly but significantly lower $(P<0.05)$ on ammonium sulphate (Fig. 1$)$. At the end of the growth experiment, the $\mathrm{pH}$ of the culture media ranged from 4.3 to 4.9 for most $\mathrm{N}$ sources, with the exception of ammonium sulphate $(\mathrm{pH}=3.6)$ and glutamate $(\mathrm{pH}=5.7)$.

Identification of Tulasnella calospora genes involved in the uptake of inorganic $\mathrm{N}$ forms

The complete genome sequence of T. calospora (Kohler et al., 2015) is available on the Mycocosm portal (http://genome.jgi. doe.gov/Tulca1/Tulca1.home.html) and was searched for fungal genes potentially involved in the uptake of inorganic $\mathrm{N}$ forms. Genes corresponding to nitrate uptake and assimilation (nitrate and nitrite reductases) could not be identified in the T. calospora genome. By contrast, three gene models coding for ammonium transporters (AMTs) were identified (corresponding to protein IDs 241632, 186135 and 10772). Only the first two, respectively named TCAMT1 and TCAMT2, contained a signal peptide, whereas the third, shorter sequence showed only partial homology with AMTs from other fungi and was not investigated further. Searches in the protein sequence databases indicated for TcAMT1 and TcAMT2 a high similarity to AMTs proteins identified in other mycorrhizal basidiomycetes, such as Hebeloma

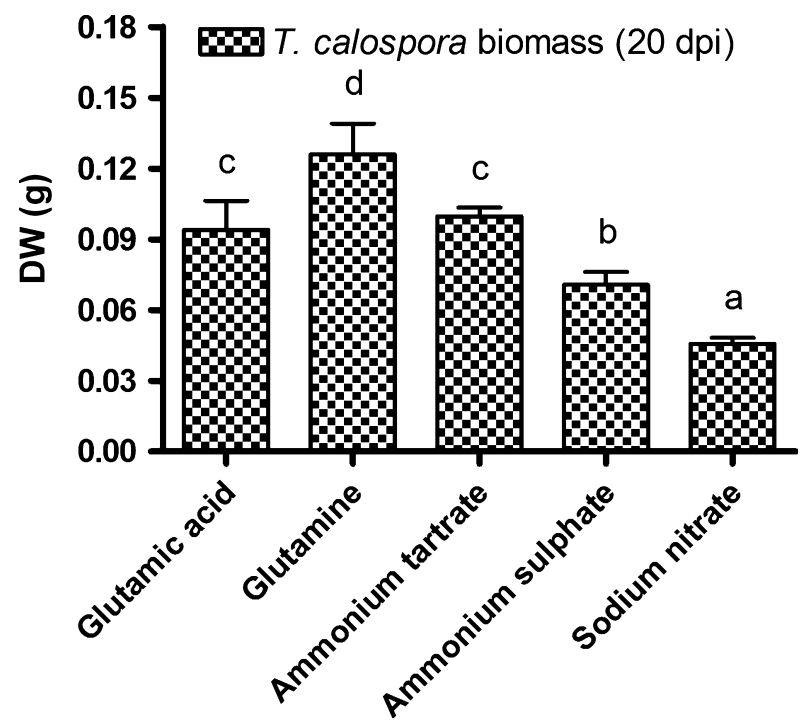

Fig. 1 Growth of Tulasnella calospora on different nitrogen (N) sources, as dry weight (DW). Biomass is expressed as mean values of three replicates $\pm S D$. ANOVA was performed comparing all five media, and values with different letters above the bars differ significantly following Tukey's honest significant difference $(H S D)$ test $(P<0.05)$. dpi, days post inoculum. cilindrosporum $(76 \%$ and $69 \%$ identity with TcAMT1 and TcAMT2, respectively) or Laccaria bicolor $(74 \%$ and $65 \%$ identity with TcMT1 and TcAMT2, respectively). Phylogenetic comparison with functionally characterized transporters from other fungi (Pérez-Tienda et al., 2011) showed that TcAMT1 clustered with high-affinity transporters, whereas TcAMT2 clustered with low-affinity transporters (Fig. 2).

\section{Heterologous expression of $T$. calospora ammonium transporters TCAMT1 and TCAMT2 in a yeast mep mutant}

To verify that TcAMT1 and TcAMT2 encode functional ammonium transporters, the corresponding cDNAs were constitutively expressed in the yeast triple mep mutant 31019b (Marini et al., 1997). This strain is unable to grow on medium containing $<5 \mathrm{mM} \mathrm{NH}_{4}{ }^{+}$as the sole $\mathrm{N}$ source because it is defective in all three endogenous Mep ammonium transporters. Both TcAMT1 and TcAMT2 were able to complement the growth defect of the

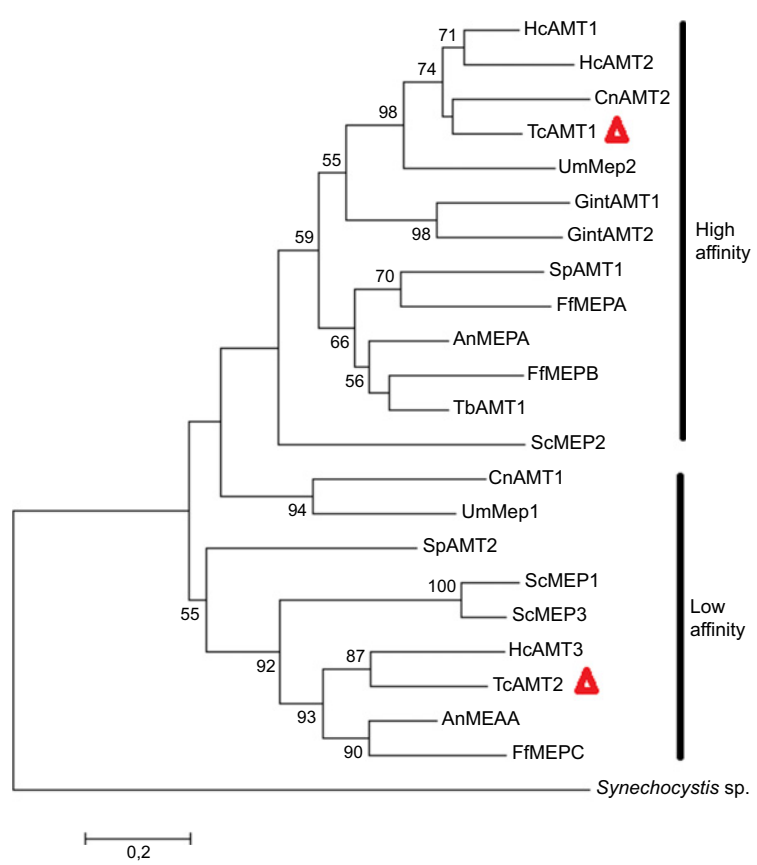

Fig. 2 Phylogenetic tree of fungal ammonium transporters, based on amino acid deduced sequences. The sequences were aligned using MUSCLE and a tree was constructed using the maximum likelihood method. Numbers indicate bootstrap values, and are given only for $\geq 50 \%$. Bootstrap tests were performed using 1000 replicates. Sequences were obtained from the GenBank database with the following accession numbers: Glomus intraradices (GintAMT1, CAI54276; GintAMT2, CAX32490), Hebeloma cylindrosporum (HcAMT1, AAM21926; HcAMT2, AAK82416; HcAMT3, AAK82417), Tuber borchii (TbAMT1, AAL11032), Ustilago maydis (UmMEP1, AAL08424; UmMEP2, AAO42611), Saccharomyces cerevisiae (ScMEP1, P40260; ScMEP2, P41948; ScMEP3, P53390), Schizosaccharomyces pombe (SpAMT1, NP_588424; SpAMT2, NP_593462), Aspergillus nidulans (AnMEAA, AAL73117; AnMEPA, AAL73118), Fusarium fujikuroi (FfMEPA, CAJ44733; FfMEPB, CAJ44734; FbMEPC, CAK55531), Cryptococcus neoformans (CnAMT1, XP_566614; CnAMT2, XP_567361), and Synechocystis sp. (NP_442561). Red arrowheads point to the Tulasnella calospora ammonium transporter sequences TCAMT1 and TCAMT2. 
mutant yeast strain in the presence of $\mathrm{NH}_{4}{ }^{+}$(from 0.1 to $1 \mathrm{mM}$ ) as the sole $\mathrm{N}$ source, demonstrating that they encode functional AMTs (Fig. 3). To assess if external pH affects their function, growth tests were performed at initial $\mathrm{pH}$ values ranging from 4.5 to 7.5 on minimal medium containing $1 \mathrm{mM} \mathrm{NH}_{4}^{+}$as the sole $\mathrm{N}$ source. Both transporters showed $\mathrm{pH}$ dependence, and growth promotion was best at acidic $\mathrm{pH}$ and strongly decreased at $\mathrm{pH} 7.5$ (Fig. 3).

\section{Expression of TCAMT1 and TCAMT2 on different $\mathrm{N}$ sources and in symbiosis}

RNA-Seq and RT-qPCR experiments were used to investigate expression of TcAMT1 and TcAMT2, as well as the expression of other T. calospora genes potentially involved in $\mathrm{N}$ uptake and metabolism, both in the free-living mycelium and in symbiosis. RNA-Seq expression data were derived from two separate experiments (illustrated in Fig. S1): RNA-Seq-A was run to identify genes differentially expressed by $T$. calospora in free-living mycelium and inside symbiotic protocorms, both obtained on oat meal, whereas RNA-Seq-B was run to investigate fungal gene expression patterns in free-living mycelia grown on two defined $\mathrm{N}$ sources, glutamine and ammonium. Gene expression in symbiosis was also measured in this second RNA-Seq experiment in order to gain some insights into $\mathrm{N}$ regulation in the protocorm environment. In the free-living mycelium grown on glutamine as the sole $\mathrm{N}$ source, expression of both TcAMT genes was reduced as compared with ammonium, but down-regulation was significant $(\mathrm{FC}<0.5$; $P=0.44$ ) only for TcAMT2 (RNA-Seq-B in Table 1 ). The results of RT-qPCR (Fig. 4) on a wider range of $\mathrm{N}$ sources indicated a low level of TcAMT1 and TcAMT2 expression when T. calospora was grown on all $\mathrm{N}$ sources, with an increase on nitrate only significant for TcAMT1 $(P<0.05)$ (Fig. 4). Of the two T. calospora AMT genes, only TcAMT2 was significantly up-regulated in symbiosis $(\mathrm{FC}=3.6$; $P<0.05)$, whereas expression of TcAMT1 was not significantly different from expression in the free-living mycelium grown on oat medium, the same medium used for symbiotic seed germination (RNA-Seq-A in Table 1; Fig. 4).
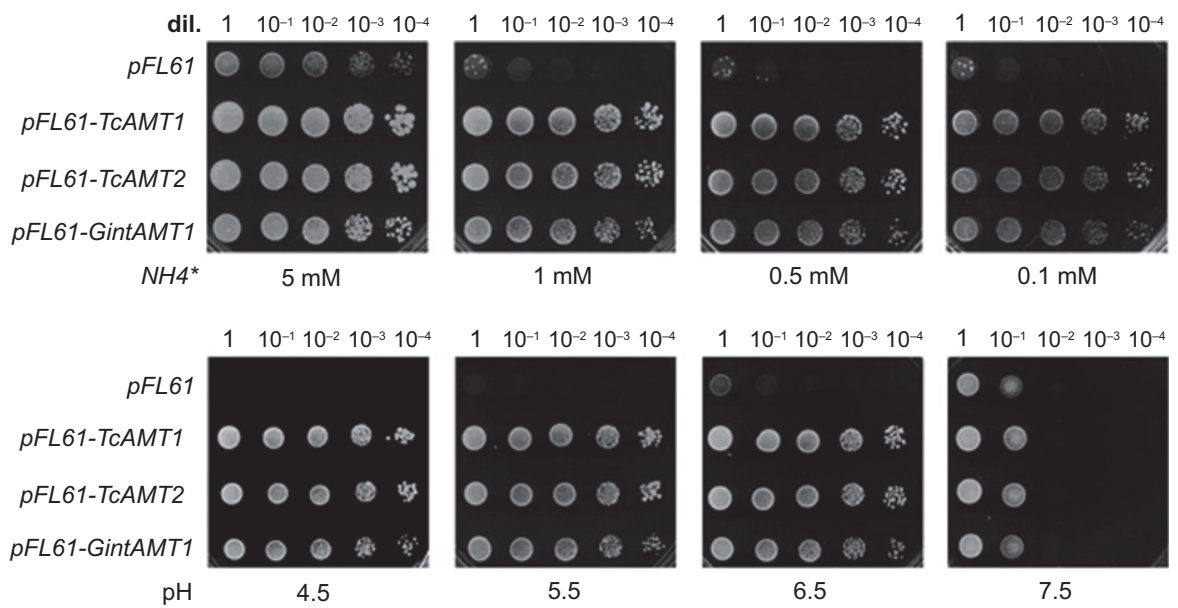
protocorms (Table 1).

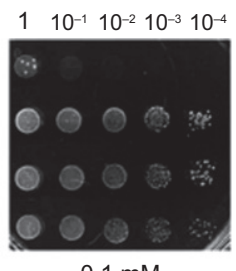

$0.1 \mathrm{mM}$

\section{Identification of $T$. calospora genes potentially involved in organic $\mathrm{N}$ uptake}

In addition to inorganic $\mathrm{N}$, the soil litter contains organic $\mathrm{N}$ forms such as amino acids, small peptides and proteins that can be absorbed by most fungi (Chalot \& Brun, 1998). Genes coding for membrane proteins potentially involved in amino acid uptake were identified in T.calospora. Significant up-regulation was recorded for only one amino acid transporter/permease gene (named TcAAT9) in free-living mycelium grown on glutamine (FC $=3.8 ; P<0.05$ ), as compared with ammonium (RNA-Seq-B in Table 1). Using ammonium as the reference $\mathrm{N}$ source, most of the other fungal amino acid transporters/permeases were not differentially expressed in the free-living mycelia grown on the two $\mathrm{N}$ sources, or they were down-regulated on glutamine $(\mathrm{FC}<0.5$; $P<0.05$ ), like TcAAT1 and TcAAT11 (Table 1).

Expression of some of the T. calospora amino acid transporters/permeases was up-regulated in symbiosis (RNA-Seq-A in Table 1). For example, TcAAT1, TcAAT2 and TcAAT6 were significantly up-regulated in mycorrhizal protocorms $(\mathrm{FC}>2.5$; $P<0.05$ ), as compared with free-living mycelia (Table 1). TcAAT1 transcripts were also detected in colonized LMD protocorm cells (Fig. S3). The expression of the other amino acid transporter/permease coding genes identified in the transcriptome was unchanged, or even down-regulated in mycorrhizal

\section{$\mathrm{N}$ assimilation and pathways in $T$. calospora}

Glutamine synthetase is an essential enzyme in $\mathrm{N}$ assimilation, and two genes coding for glutamine synthetase (named TcGS1

Fig. 3 Complementation of the ammonium permease (mep) yeast mutant with Tulasnella calospora ammonium transporters TCAMT1 and TCAMT2. The ammonium uptake-deficient yeast 31019b ( $\Delta \Delta \Delta$ mep1;2;3) was transformed with TCAMT1, TCAMT2, the positive control Rhizophagus irregularis GintAMT and the empty plasmid pFL61 as a negative control. Serial dilutions of the transformants were grown on ammonium as the sole nitrogen (N) source at different concentrations and $\mathrm{pH}$ or on arginine as a positive growth control. 


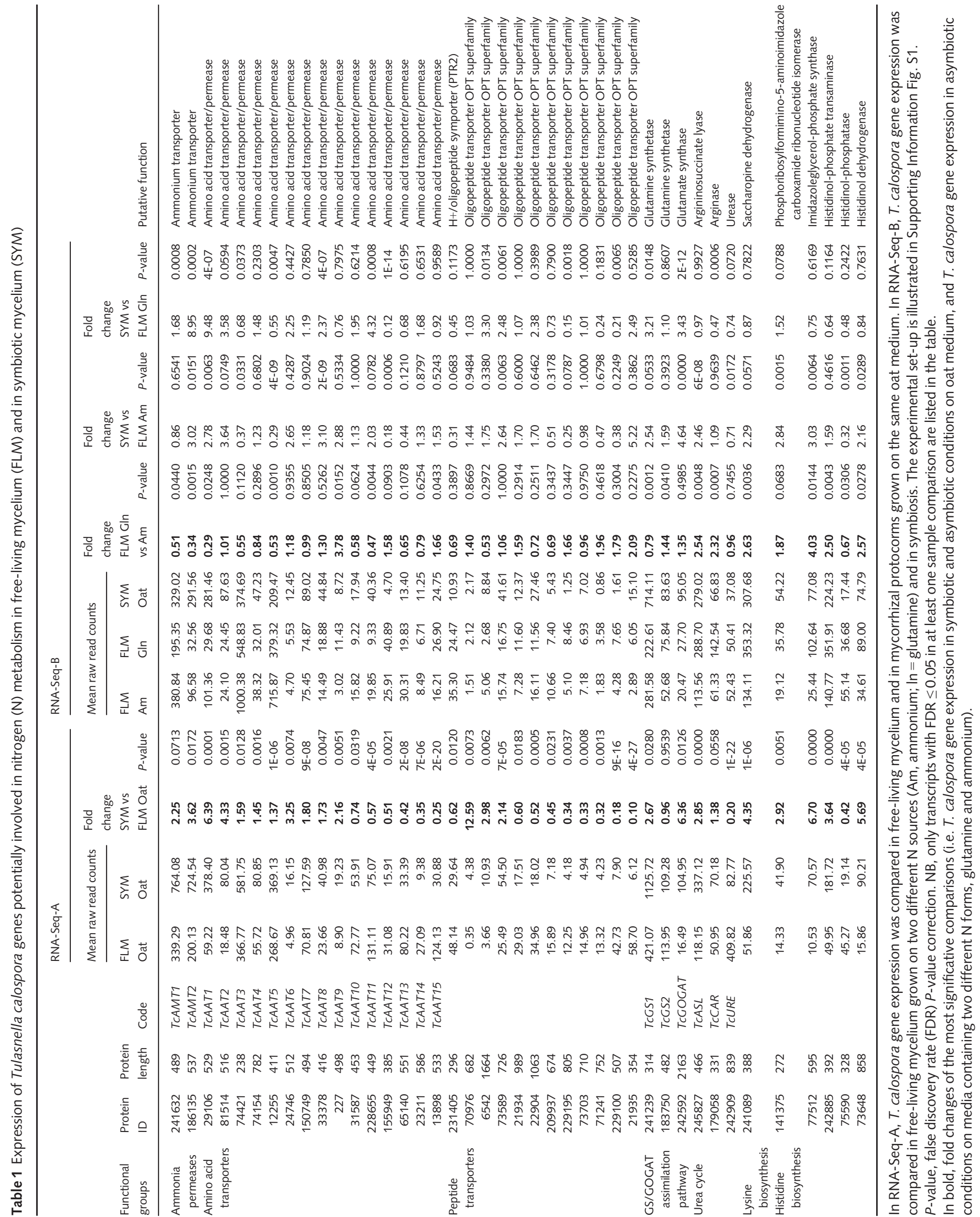



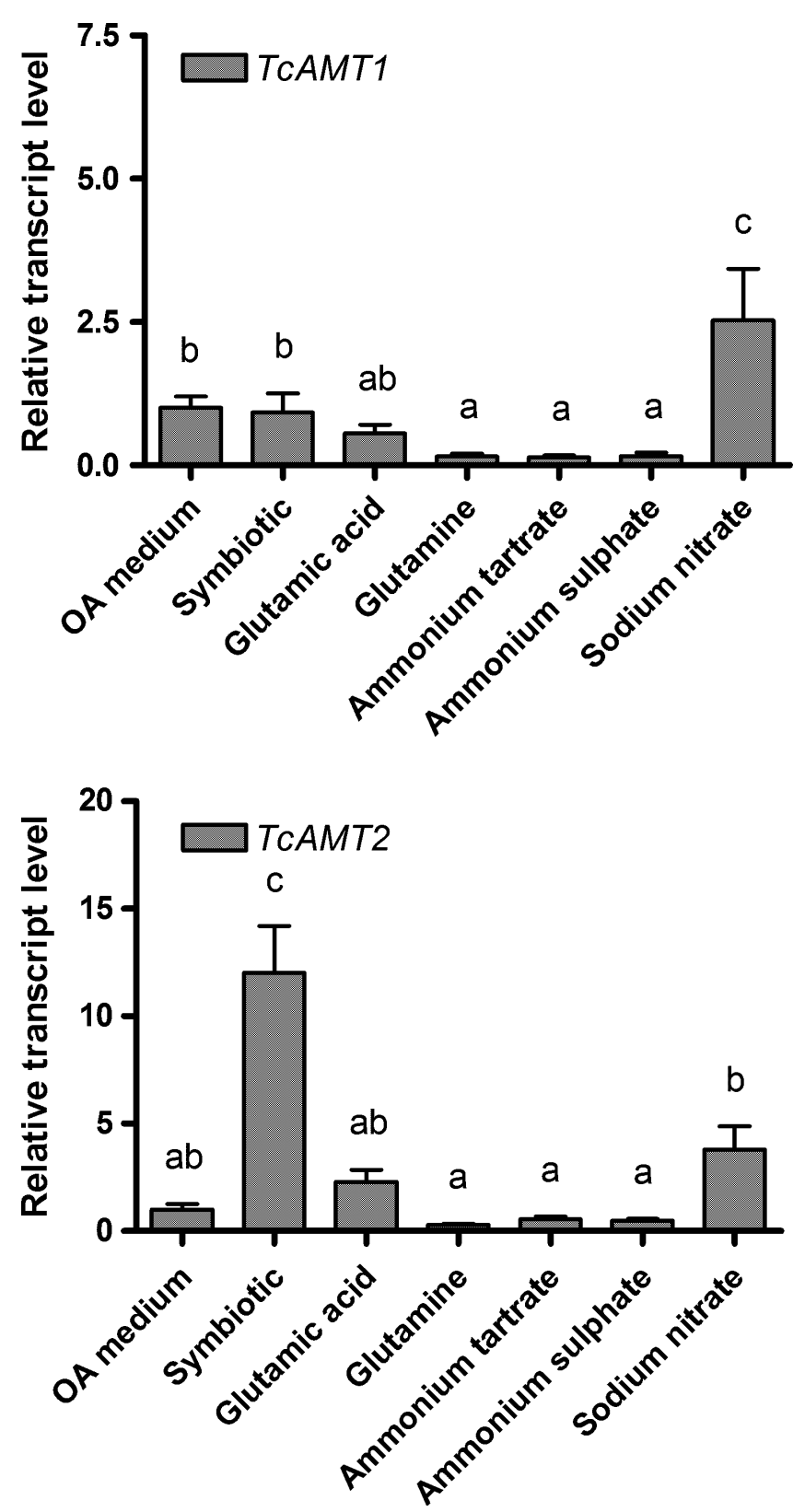

Fig. 4 Quantification by quantitative real-time polymerase chain reaction (qPCR) of the expression of the T. calospora ammonium transporter genes TCAMT1 and TCAMT2 in free-living mycelium grown on different organic and inorganic nitrogen $(\mathrm{N})$ sources and in symbiosis. Gene expression was calculated as the expression ratio relative to the free-living mycelium grown on oat medium (relative transcript level). Different lowercase letters above the bars denote significant differences by Tukey's honest significant difference (HSD) test $(P<0.05)$. Results are mean values of three biological and three technical replicates $\pm S D$. OA, oat agar.

and TcGS2) were identified in the T.calospora genome. Their expression in free-living mycelium did not change on ammonium- or glutamine-containing media (Table 1), although TcGS1 was more strongly expressed (as a raw read number) and up-regulated in symbiosis $(\mathrm{FC}=2.7 ; P<0.05)$. Both $T c G S 1$ and TcGS2 transcripts could be amplified from laser microdissected protocorm cells containing fungal pelotons (Fig. S3). The
T. calospora gene coding for glutamate synthase, the other enzyme taking part in the $\mathrm{N}$ assimilation pathway, was also up-regulated $(\mathrm{FC}=6.4 ; P<0.05)$ in mycorrhizal protocorms (Table 1).

As no information is currently available on the $\mathrm{N}$ pathways inside orchid mycorrhizas, we investigated in T. calospora the expression of some genes identified in other mycorrhizal fungi. In particular, the urea cycle is a pathway reported for both AM (Tian etal., 2010; Koegel etal., 2015) and ECM fungi (Morel etal., 2005; Wright etal., 2005). Argininosuccinate lyase is involved in arginine biosynthesis and is a key enzyme of the anabolic arm of the urea cycle; in the T. calospora free-living mycelium, the corresponding gene was found to be slightly induced by glutamine $(\mathrm{FC}=2.5 ; P<0.05)$, as compared with ammonium (Table 1). This gene was induced in symbiosis $(\mathrm{FC}=2.9 ; P<0.05)$. Arginase and urease are two enzymes of the catabolic arm of the urea cycle and are involved in arginine breakdown; in the current model of the N pathway in AM, they are thought to release ammonium from arginine in the intraradical hyphae of AM fungi (Tian et al., 2010). Arginase (CAR) gene expression was investigated in T. calospora by RNA-Seq (Table 1). Only one of the three T. calospora gene models coding for arginase (TcCAR; protein ID 179058) was found in the transcriptome, but it was not differentially expressed on different $\mathrm{N}$ sources or in symbiosis. By contrast, TcURE, coding for the T. calospora urease (protein ID 242909), showed a strong and significant down-regulation $(\mathrm{FC}=0.2 ; \quad P<0.05)$ in symbiosis (Table 1).

\section{Serapias vomeracea gene expression in symbiotic and asymbiotic protocorms}

As the genome of $S$. vomeracea has not yet been sequenced, a de novo assembly of S. vomeracea transcripts was generated and contigs were annotated by BLASTX searches against the A. thaliana (TAIR) and the P.equestris (Cai et al., 2015) proteomes. Although de novo assembly was highly fragmented and only included sequences derived from asymbiotic protocorms, it represented a useful tool to identify genetic functions that were then validated by RT-qPCR. A list of contigs that, based on their annotation in A.thaliana, may be related to $\mathrm{N}$ uptake in S. vomeracea and their level of expression in symbiotic and asymbiotic protocorms can be found in Table 2. Two contigs annotated as ammonium transporters, named, respectively, SvAMT1 and SvAMT2, showed upregulation in symbiotic protocorms, but their induction was not statistically significant in the RNA-Seq experiment (Table 2). RT-qPCR demonstrated that SvAMT1 was slightly but significantly up-regulated $(\mathrm{FC}=2.5 ; P<0.05)$ in symbiotic protocorms, whereas SvAMT2 was not up-regulated (Fig. 6). Phylogenetic comparison with plant AMTs (Guether etal., 2009) confirmed that SvAMT1 and SvAMT2 cluster together with other members of the AMT1 and AMT2 subfamilies, respectively (Fig. S4).

Several contigs in the S. vomeracea transcriptome matched genes annotated as amino acid transporters/permeases in the A. thaliana and P. equestris genomes. Only contigs manually 

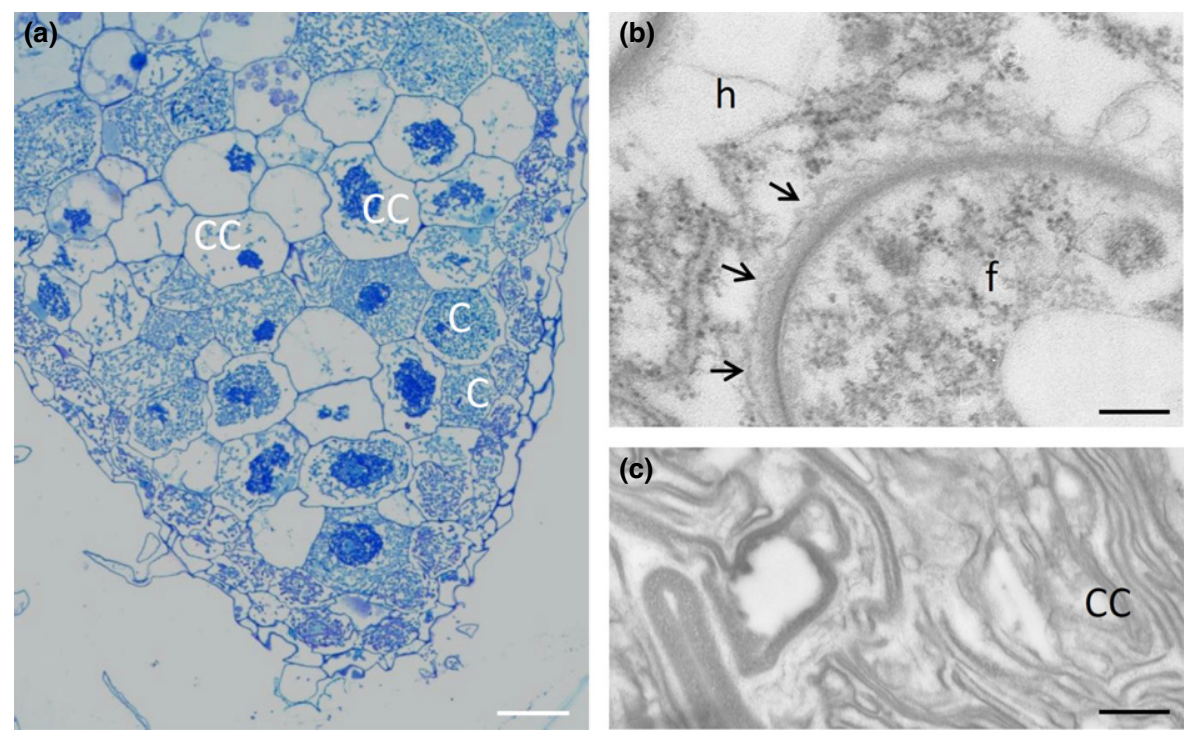

Fig. 5 Mycorrhizal protocorms of Serapias vomeracea $30 \mathrm{~d}$ after sowing with Tulasnella calospora. (a) Semi-thin section of a resin-embedded protocorm, showing the basal mycorrhizal region. Colonized cells containing hyphal pelotons (coils) at different stages of development correspond to the laser microdissected cell types: cells containing younger, well-developed pelotons occupying the whole plant cell (C), and cells containing older, more condensed or collapsing fungal pelotons (CC). (b) Under the electron microscope, an interfacial matrix surrounded by plant membrane proliferation (arrows) can be seen around an intracellular hypha (f) inside the host plant cell (h). (c) A colonized protocorm cell containing a collapsed coil (CC). Bars: (a) $80 \mu \mathrm{m}$; (b) $0.25 \mu \mathrm{m}$; (c) $0.35 \mu \mathrm{m}$.

verified by BLASTX and with FDR $\leq 0.05$ are reported in Table 2 . Some of them were validated by RT-qPCR, which confirmed the RNA-Seq results (Fig. 6). Two contigs coding for amino acid permeases (SvAAP1 and SvAAP2) and a contig with very high identity with lysine histidine transporter 1 (LHT1) in BLASTP searches ( $S v L H T$ ) were the most up-regulated in symbiotic protocorms (Table 2). Interestingly, the strong up-regulation of SvLHT expression in symbiosis was accompanied by the up-regulation of the biosynthetic pathways for lysine and histidine in the symbiotic fungus (RNA-Seq-A in Table 1). Histidinol dehydrogenase, the gene coding for the last steps in histidine biosynthesis, was significantly up-regulated inside mycorrhizal protocorms $(\mathrm{FC}=5.7 ; P<0.05)$. One sequence corresponding to saccharopine dehydrogenase, the final enzyme responsible of lysine biosynthesis (protein ID 241089), was also up-regulated $(\mathrm{FC}=4.4 ; P<0.05)$ in symbiosis (Table 1$)$.

Because of the role of glutamine synthetase in $\mathrm{N}$ assimilation, we looked for the corresponding $S$. vomeracea contigs in the transcriptome (Table 2). Although the expression level was not very high in terms of raw read numbers, one contig $(S v G S)$ was significantly up-regulated $(\mathrm{FC}=245 ; P<0.05)$ in mycorrhizal protocorms (Table 2), a situation confirmed by RT-qPCR (Fig. 6).

\section{Discussion}

\section{$\mathrm{N}$ preference in orchid mycorrhizal fungi}

Orchids are peculiar mycorrhizal partners because they acquire all nutrients through the fungal symbiont, including organic $\mathrm{C}$, at least during the mycoheterotrophic life stages (Smith \& Read, 2008; Selosse \& Martos, 2014). For terrestrial orchids associated with Tulasnella, Ceratobasidium and Sebacinales, nutrients probably derive from organic compounds available in soil because these fungi are known saprotrophs that utilize soil nutrient sources for growth and survival (Smith \& Read, 2008; Waterman etal., 2011). Nurfadilah etal. (2013) reported different $\mathrm{N}$ source preference in orchid mycorrhizal fungi because isolates in the genus Tulasnella could use ammonium but not nitrate as inorganic $\mathrm{N}$ forms, whereas isolates in the genus Ceratobasidium could use both ammonium and nitrate. Growth of T. calospora isolate AL13/4D on different $\mathrm{N}$ sources confirmed a preference for ammonium and organic $\mathrm{N}$ sources, like other cultivable orchid mycorrhizal fungi (Hadley \& Ong, 1978; Nurfadilah et al., 2013). The different abilities of Tulasnella and Ceratobasidium to use inorganic $\mathrm{N}$ forms is probably explained by the fact that the T. calospora genome lacks genes involved in nitrate uptake and reduction, whereas these genes could be found in the recently sequenced genome of a Ceratobasidium sp. isolate, available on the Mycocosm portal (http://genome.jgi.doe.gov/ CerAGI/CerAGI.home.html). The ability of orchid mycorrhizal fungi to use different $\mathrm{N}$ sources has important ecological implications because most photoautotrophic orchids host a diverse community of orchid mycorrhizal fungi in their roots and protocorms, often including both Tulasnella and Ceratobasidium species (see e.g. Jacquemyn et al., 2010; Girlanda et al., 2011; Ercole etal., 2015). Co-occurrence of fungal symbionts able to utilize a wide variety of nutrient sources and to exploit different soil $\mathrm{N}$ forms would represent an advantage for the host plant because it could broaden the habitat range as well as the ability of the orchid to grow in a wide range of soil types (Nurfadilah et al., 2013). 


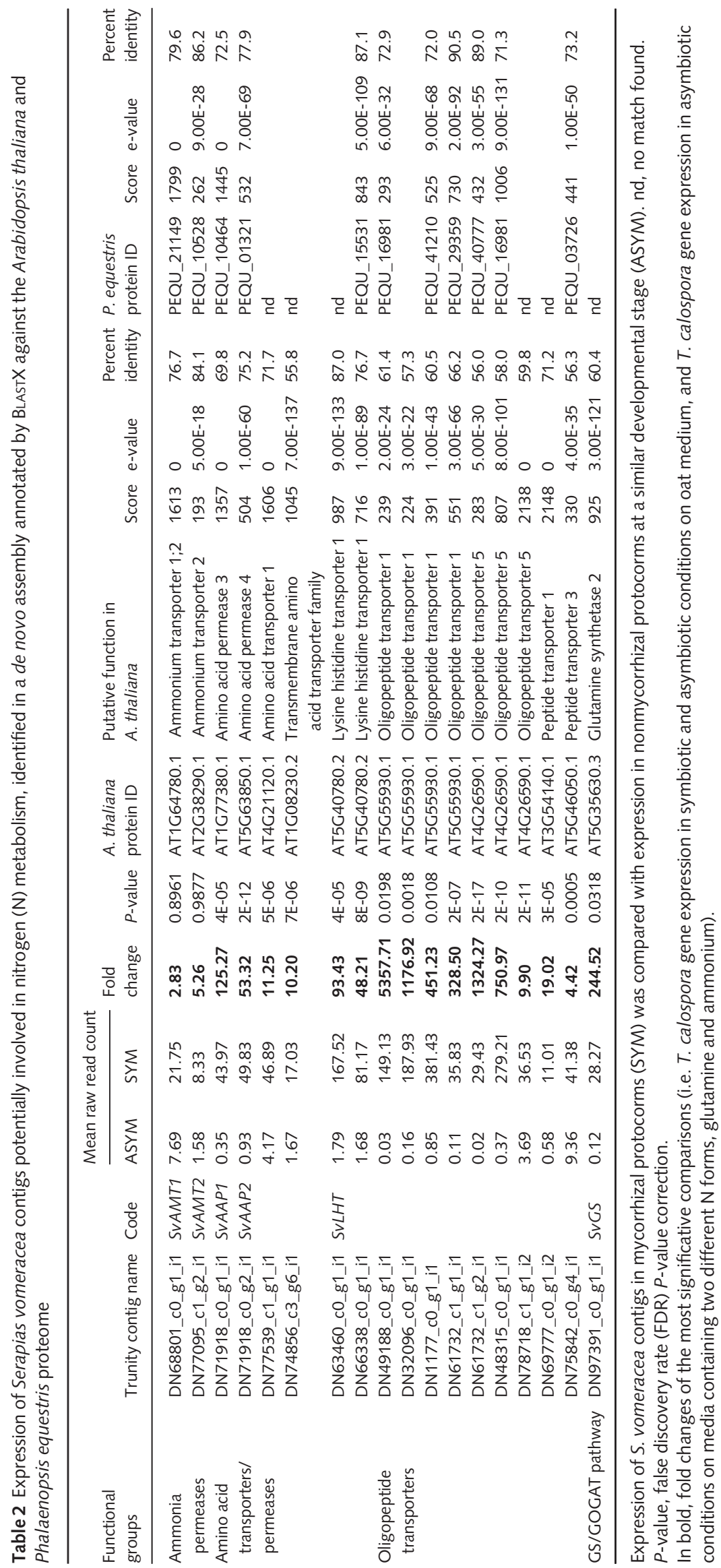



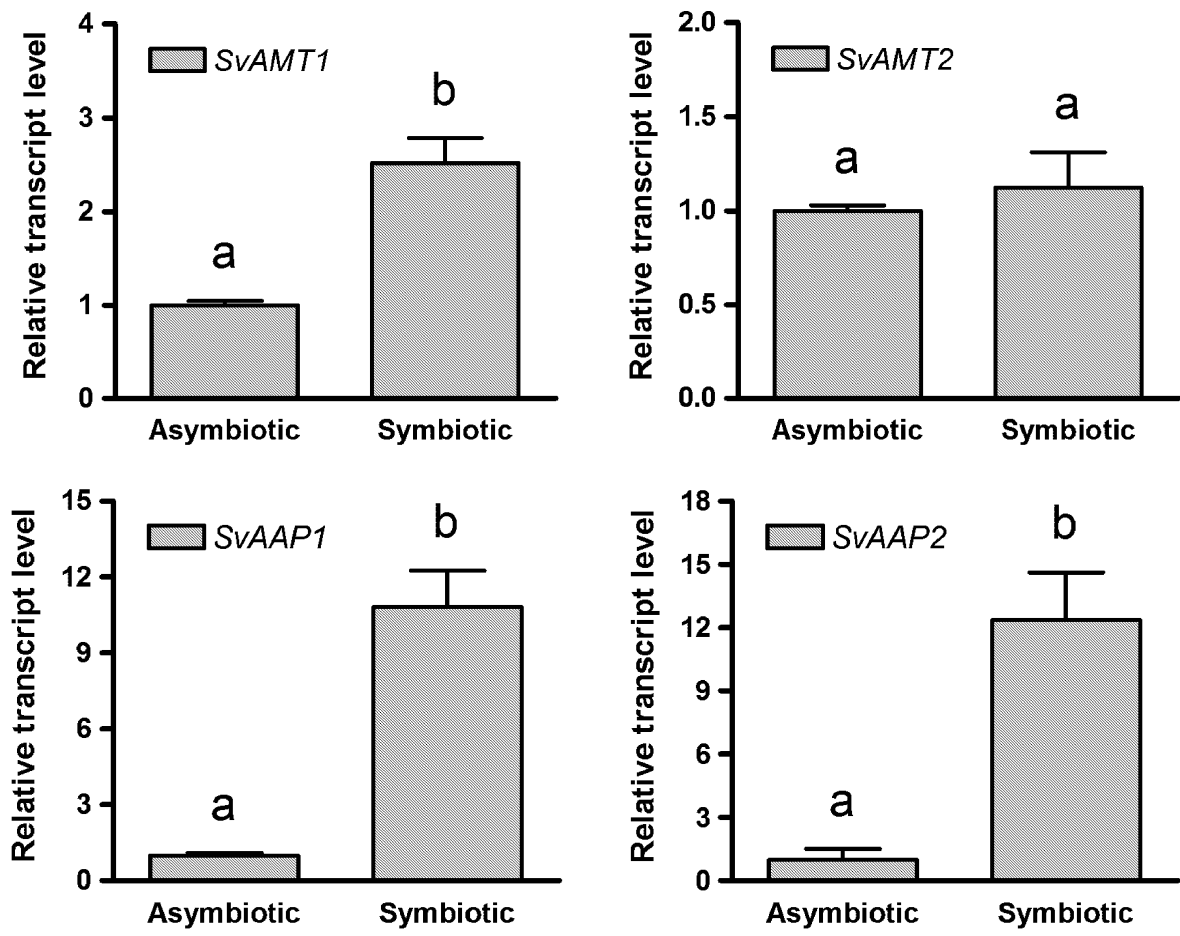

Fig. 6 Quantitative real-time polymerase chain reaction ( $q P C R$ ) assessing the expression of several Serapias vomeracea contigs in symbiotic and asymbiotic protocorms. Gene expression was calculated as the expression ratio relative to asymbiotic protocorms (relative transcript level). Different lowercase letters above the bars denote significant differences by two-tailed Student's $t$-test $(P<0.05)$. Results are mean values of three biological and three technical replicates \pm SD.
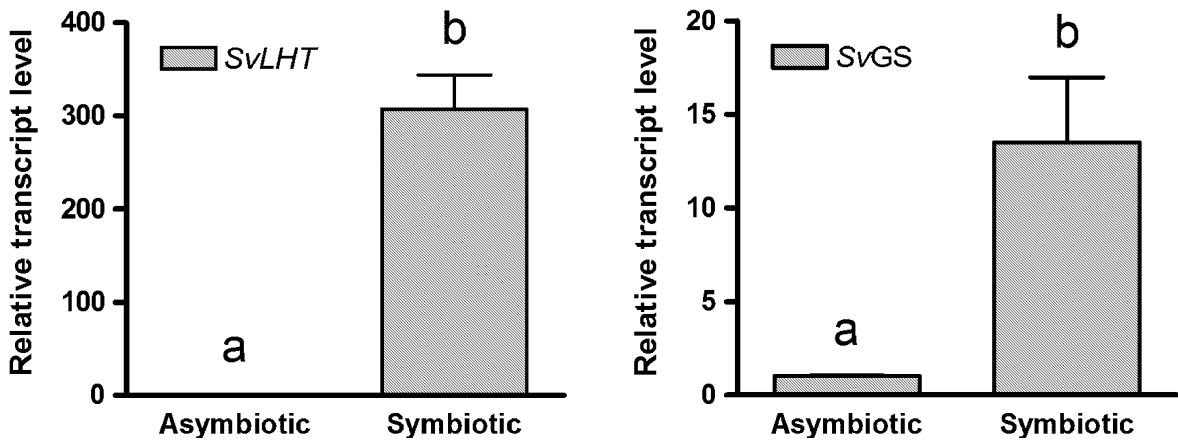

\section{$\mathrm{N}$ pathways in the fungal hyphae}

In the current model proposed for AM fungi, the best studied among mycorrhizal fungi, $\mathrm{N}$ taken up by the extraradical fungal mycelium as inorganic (Bago et al., 1996; Govindarajulu et al., 2005) or organic (Hawkins et al., 2000; Cappellazzo et al., 2008; Belmondo et al., 2014) $\mathrm{N}$ forms is assimilated into arginine via the biosynthetic arm of the urea cycle (Bago et al., 2001). Arginine is then transported to the intraradical mycelium, where it is broken down via the catabolic arm of the urea cycle to release ammonium (see Bücking \& Kafle, 2015). The free ammonium is released into the plant-fungus interface, where it is taken up by the host plant through local induction of plant ammonium transporters (Gomez etal., 2009; Guether etal., 2009; Kobae etal., 2010; Koegel et al., 2013). This inorganic $\mathrm{N}$ form is then assimilated in the plant cytoplasm through the up-regulation of the plant GS/GOGAT pathway (Bücking \& Kafle, 2015). The urea cycle also seems to be involved in the $\mathrm{N}$ pathway of some ECM fungi, as urea was found to accumulate in the extraradical mycelium together with gene transcripts related to the urea cycle (Morel et al., 2005; Wright et al., 2005).
Although solely based on transcriptional evidence, it seems unlikely that T.calospora uses this $\mathrm{N}$ pathway to transfer ammonium to the orchid protocorm because the gene coding for urease, the main enzyme involved in arginine breakdown and ammonium release, is up-regulated in the intraradical AM fungal mycelium (Koegel et al., 2015) but strongly down-regulated in the symbiotic T.calospora. Moreover, argininosuccinate lyase, a marker gene of arginine biosynthesis up-regulated in the extraradical AM fungal mycelium (Koegel etal., 2015), was instead up-regulated in symbiosis in T. calospora. It should, however, be noted that, also as a consequence of the obligate symbiotic nature of AM fungi, gene expression and enzymatic activities in AM fungi were assessed in two different but connected compartments, that is, the extraradical and intraradical AM fungal mycelium (Gomez etal., 2009; Tian etal., 2010; Koegel etal., 2015), whereas gene expression in T.calospora was measured separately in free-living mycelium and symbiotic conditions. The metabolic pathway and the form of $\mathrm{N}$ transferred inside the T. calospora hyphae that connect the substrate to the protocorm remain therefore to be understood. 


\section{$\mathrm{N}$ transfer inside the mycorrhizal orchid protocorm}

One way to elucidate the form of $\mathrm{N}$ delivered by the mycorrhizal fungus in symbiosis is to investigate the plant import system. For example, ammonium transfer in AM symbiosis is suggested by the high and localized up-regulation of plant AMTs in arbusculecontaining cells (Gomez et al., 2009; Guether et al., 2009; Kobae et al., 2010; Koegel et al., 2013). In Lotus japonicus, LjAMT2;2 was the most up-regulated gene in mycorrhizal roots (Guether et al., 2009). In our orchid mycorrhizal system, by contrast, the importance of ammonium transfer to the plant remains unclear because the two S. vomeracea SvAMT1 and SvAMT2 genes were weakly expressed (as raw read numbers) and not strongly up-regulated in mycorrhizal protocorms.

Some putative S. vomeracea transporters strongly induced in mycorrhizal protocorms suggest transfer of organic $\mathrm{N}$ forms to the host plant in orchid mycorrhizas. In addition to some amino acid transporters/permeases, S. vomeracea contigs coding for a putative lysine histidine transporter 1 (LHT1) were found to be very highly up-regulated in mycorrhizal protocorms. Upregulation of genes coding for LHT1 in mycorrhizal roots has also been demonstrated by deep sequencing in the tropical orchid Cymbidium hybridum (Zhao et al., 2014) and in L. japonicus AM roots (Guether et al., 2011), suggesting a role during symbiosis. LHT1 was first identified in A. thaliana and AtLHT1 was originally reported as a lysine and histidine selective transporter (Chen $\&$ Bush, 1997), but later studies showed that LHTs can transport quite a broad range of amino acids (Hirner et al., 2006; Guether et al., 2011). Further experiments are therefore needed to characterize the putative LHT1 identified in this work.

Cameron et al. (2006) suggested amino acid transfer in orchid mycorrhizas, based on incorporation of both ${ }^{13} \mathrm{C}$ and ${ }^{15} \mathrm{~N}$ in mycorrhizal G. repens after feeding the symbiotic fungus with double-labelled $\left[{ }^{13} \mathrm{C}-{ }^{15} \mathrm{~N}\right]$ glycine. In Cameron et al.'s experiment, the ratio of assimilated ${ }^{13} \mathrm{C}:{ }^{15} \mathrm{~N}$ recovered in the extraradical fungus and in orchid mycorrhizal roots was significantly lower than the ratio in the source glycine. As discussed by these authors, if co-transport of glycine-derived ${ }^{15} \mathrm{~N}$ and ${ }^{13} \mathrm{C}$ occurred as amino acids with a higher $\mathrm{N}$ content, such as glutamine, the transamination could account for the change in the ${ }^{13} \mathrm{C}:{ }^{15} \mathrm{~N}$ ratio (Cameron et al., 2006). Although substrate specificity of the $S$. vomeracea LHTs remains to be established, we can speculate that the amino acids preferentially transferred may be $\mathrm{N}$-enriched amino acids such as arginine, lysine or histidine, as suggested by the RNA-Seq data showing that the biosynthetic pathways of these amino acids are up-regulated in T. calospora when inside the mycorrhizal protocorm.

In addition to transporters/permeases for single amino acids, several S. vomeracea contigs identified as putative oligopeptide transporters were very strongly up-regulated in symbiotic protocorms (Table 2), similarly to what has been observed in mycorrhizal roots of Cymbidium hybridum (Zhao etal., 2014). However, the role of oligopeptide transporters in $\mathrm{N}$ transport is unclear, as these transporters seem to be also involved in the transport of metals and glutathione (Lubkowitz, 2011).

\section{$\mathrm{N}$ uptake by $T$. calospora inside mycorrhizal protocorm cells}

Fungal gene expression in mycorrhizal protocorms suggests that ammonium is available in the apoplastic interface surrounding the pelotons and is actively taken up by the fungus. In particular, the strong induction of a low-affinity ammonium transporter (TcAMT2) and of the ammonium scavenging enzyme glutamine synthetase (TcGS1) suggests that ammonium is at high concentrations in the plant-fungus interface and is rapidly assimilated once taken up by the fungal peloton. Fungal transcripts corresponding to high- and low-affinity AMTs in root colonized cells have been reported in AM fungi (Pérez-Tienda et al., 2011; Calabrese et al., 2016), where a role in ammonium retrieval from the apoplastic interface surrounding the arbuscule has been suggested. As hypothesized for AM fungi (Guether et al., 2009; Calabrese et al., 2016), the presence of both fungal and plant AMTs in the same colonized orchid cells may lead to a competition between the plant and the fungus for $\mathrm{N}$ present in the interfacial apoplast.

\section{Conclusions}

In the present study, we have identified for the first time some genetic determinants potentially involved in $\mathrm{N}$ uptake and transfer in orchid mycorrhizas. The T. calospora genome contains two genes coding for functional ammonium transporters and several amino acid transporters/permeases that allow this fungus to exploit organic and inorganic $\mathrm{N}$ sources (but not nitrate). Based on transcriptional evidence, we suggest that organic $\mathrm{N}$ is mainly transferred to the host plant, possibly in the form of $\mathrm{N}$-rich amino acids. The transfer of amino acids with a high $\mathrm{N}: \mathrm{C}$ ratio would explain the unusually high $\mathrm{N}$ content in orchid tissues (Hynson et al., 2013).

Up-regulation in symbiosis of plant and fungal genes coding for membrane transporters suggests active transport processes in orchid mycorrhiza. However, our findings do not exclude a role of pelotons lysis in nutrient transfer, and the strong induction of plant amino acid and oligopeptide transporters may reflect recovery of organic $\mathrm{N}$ forms from collapsing hyphae. Further studies on the expression of these plant genes in laser microdissected protocorm cells containing pelotons at different stages of development may help to elucidate this point.

Recent studies in AM interactions have demonstrated that reciprocal reward strategies guarantee a 'fair trade' between the two mycorrhizal partners, where phosphorus and $\mathrm{N}$ from the fungus are exchanged against $\mathrm{C}$ from the plant (Kiers et al., 2011; Fellbaum etal., 2012). In particular, increased C supply to the mycorrhizal fungus by the host plant was found to stimulate the uptake and transfer of inorganic and organic $\mathrm{N}$ in the fungal partner (Fellbaum etal., 2012). In this respect, orchids raise intriguing questions about the mechanisms controlling the nutrient flux, at least during the mycoheterotrophic stages (Selosse $\&$ Rousset, 2011). In fact, orchid mycorrhizal fungi provide the plant not only with N (Cameron et al., 2006; Kuga et al., 2014) and P (Cameron et al., 2007) but also with organic C, without an apparent reward (Selosse \& Roy, 2009). What drives nutrient 
flow towards the plant in the absence of a bidirectional exchange remains one of the most fascinating questions in orchid mycorrhizas (Selosse \& Rousset, 2011). The identification of the molecular components involved in this nutrient flow may provide some tools with which to start addressing this question.

\section{Acknowledgements}

We thank Nuria Ferrol (CSIC) for kindly providing the S. cerevisiae isolates for functional complementation, Enrico Ercole, Stefania Daghino, Antonella Faccio and Alessandro Lopa for technical help and Roland Marmeisse for critical reading of the manuscript. We also thank the anonymous reviewers for their valuable comments. V.F. was supported by a $\mathrm{PhD}$ fellowship from MIUR. The research was partly supported by local funding from the University of Turin (2014-2015) and was performed in the frame of the IPSP research line 'Biodiversità in sistemi agrari e forestali: basi genetiche, epigenetiche e molecolari' (AG.AP04.025). The LMD system up-grade was possible thanks to the financial support of the 'Compagnia di San Paolo' (Torino, Italy). RNA sequencing has been carried out at the US Department of Energy (DOE) Joint Genome Institute (contract no. DE AC02 05CH11231) within the framework of the Community Sequencing Project \#978 'The Mycorrhizal Genomics Initiative: Exploring the Symbiotic Transcriptomes' (to F.M.). Research in the laboratory of F.M. is funded by the Laboratory of Excellence Advanced Research on the Biology of Tree and Forest Ecosystems (ARBRE; grant ANR 11 LABX 0002 01) and the US DOE through the Oak Ridge National Laboratory Scientific Focus Area for Genomics Foundational Sciences (Plant Microbe Interfaces Project). [Correction added after online publication 11 November 2016: in the preceding text additional acknowledgements have been inserted.]

\section{Author contributions}

S.P., R.B. and M.G. conceived and designed the research. V.F. and W.C. conducted all wet lab experiments. S.V. prepared the biological materials and extracted the RNA for the cDNA libraries. A.K., V.R.S., E.L., K.B., I.V.G. and F.M. supervised and/or conducted the transcriptome sequencing and the bioinformatic analyses. S.P. and R.B. wrote the manuscript. All authors read and approved the manuscript.

\section{References}

Baggerly K, Deng L, Morris J, Aldaz C. 2003. Differential expression in SAGE: accounting for normal between-library variation. Bioinformatics 19: 14771483.

Bago B, Pfeffer P, Shachar-Hill Y. 2001. Could the urea cycle be translocating nitrogen in the arbuscular mycorrhizal symbiosis? New Phytologist 149: 4-8.

Bago B, Vierheilig H, Piché Y, Azcón-Aguilar C. 1996. Nitrate depletion and $\mathrm{pH}$ changes induced by the extraradical mycelium of the arbuscular mycorrhizal fungus Glomus intraradices grown in monoxenic culture. New Phytologist 133: 273-280.

Balestrini R, Gomez-Ariza J, Lanfranco L, Bonfante P. 2007. Laser microdissection reveals that transcripts for five plant and one fungal phosphate transporter genes are contemporaneously present in arbusculated cells. Molecular Plant-Microbe Interactions 20: 1055-1062.

Belmondo S, Fiorilli V, Pérez-Tienda J, Ferrol N, Marmeisse R, Lanfranco L. 2014. A dipeptide transporter from the arbuscular mycorrhizal fungus Rhizophagus irregularis is upregulated in the intraradical phase. Frontiers in Plant Science 5: 436.

Benjdia M, Rikirsch E, Muller T, Morel M, Corratge C, Zimmermann S, Chalot M, Frommer WB, Wipf D. 2006. Peptide uptake in the ectomycorrhizal fungus Hebeloma cylindrosporum: characterization of two diand tripeptide transporters (HcPTR2A and B). New Phytologist 170: 401-410.

Bücking H, Kafle A. 2015. Role of arbuscular mycorrhizal fungi in the nitrogen uptake of plants: current knowledge and research gaps. Agronomy 5: 587-612.

Cai J, Liu X, Vanneste K, Proost S, Tsai WC, Liu KW, Chen LJ, He Y, Xu Q, Bian C et al. 2015. The genome sequence of the orchid Phalaenopsis equestris. Nature Genetics 47: 65-72.

Calabrese S, Pérez-Tienda J, Ellerbeck M, Arnould C, Chatagnier O, Boller T, Schüßler A, Brachmann A, Wipf D, Ferrol N et al. 2016. GintAMT3 a lowaffinity ammonium transporter of the arbuscular mycorrhizal Rhizophagus irregularis. Frontiers in Plant Science 7: 679.

Cameron DD, Johnson I, Leake JR, Read DJ. 2007. Mycorrhizal acquisition of inorganic phosphorus by the green-leaved terrestrial orchid Goodyera repens. Annals of Botany 99: 831-834.

Cameron DD, Johnson I, Read DJ, Leake JR. 2008. Giving and receiving: measuring the carbon cost of mycorrhizas in the green orchid Goodyera repens. New Phytologist 180: 176-184.

Cameron DD, Leake JR, Read DJ. 2006. Mutualistic mycorrhiza in orchids: evidence from plant-fungus carbon and nitrogen transfers in the green-leaved terrestrial orchid Goodyera repens. New Phytologist 171: 405-416.

Cappellazzo G, Lanfranco L, Fitz M, Wipf D, Bonfante P. 2008. Characterization of an amino acid permease from the endomycorrhizal fungus Glomus mosseae. Plant Physiology 147: 429-437.

Chalot M, Blaudez D, Brun A. 2006. Ammonia: a candidate for nitrogen transfer at the mycorrhizal interface. Trends in Plant Science 11: 263-266.

Chalot M, Brun A. 1998. Physiology of organic nitrogen acquisition by ectomycorrhizal fungi and ectomycorrhizas. Federation of European Microbiological Societies, Microbiology Reviews 22: 21-44.

Chang S, Puryear J, Carney J. 1993. A simple and efficient method for isolating RNA from pine trees. Plant Molecular Biology Reporter 11: 113-116.

Chen L, Bush DR. 1997. LHT1, a lysine- and histidine-specific amino acid transporter in Arabidopsis. Plant Physiology 115: 1127-1134.

Couturier J, Montanini B, Martin F, Brun A, Blaudez D, Chalot M. 2007. The expanded family of ammonium transporters in the perennial poplar plant. New Phytologist 174: 137-150.

Dawson TE, Mambelli S, Plamboeck AH, Templer PH, Tu KP. 2002. Stable isotopes in plant ecology. Annual Reviews in Ecology and Systematics 33: 507-559.

Edgar RC. 2004. MUSCLE: multiple sequence alignment with high accuracy and high throughput. Nucleic Acids Research 32: 1792-1797.

Ercole E, Adamo M, Rodda M, Gebauer G, Girlanda M, Perotto S. 2015. Temporal variation in mycorrhizal diversity and carbon and nitrogen stable isotope abundance in the wintergreen meadow orchid Anacamptis morio. New Phytologist 205: 1308-1319.

Ercole E, Rodda M, Molinatti M, Voyron S, Perotto S, Girlanda M. 2013. Cryopreservation of orchid mycorrhizal fungi: a tool for the conservation of endangered species. Journal of Microbiological Methods 93: 134-137.

Fellbaum CR, Gachomo EW, Beesetty Y, Choudhari S, Strahan GD, Pfeffer PE, Kiers ET, Bücking H. 2012. Carbon availability triggers fungal nitrogen uptake and transport in arbuscular mycorrhizal symbiosis. Proceedings of the National Academy of Sciences, USA 109: 2666-2671.

Gebauer G, Meyer M. 2003. ${ }^{15} \mathrm{~N}$ and ${ }^{13} \mathrm{C}$ natural abundance of autotrophic and mycoetherotrophic orchids provides insight into nitrogen and carbon gain from fungal association. New Phytologist 160: 209-223.

Gietz RD, Schiestl RH. 2007. High-efficiency yeast transformation using the LiAc/SS carrier DNA/PEG method. Nature Protocols 2: 31-34.

Girlanda M, Segreto R, Cafasso D, Liebel HT, Rodda M, Ercole E, Cozzolino S, Gebauer G, Perotto S. 2011. Photosynthetic mediterranean meadow orchids feature partial mycoheterotrophy and specific mycorrhizal associations. American Journal of Botany 98: 1148-1163. 
Gomez SK, Javot H, Deewatthanawong P, Torres-Jerez I, Tang Y, Blancaflor E, Udvardi MK, Harrison MJ. 2009. Medicago truncatula and Glomus intraradices gene expression in cortical cells harboring arbuscules in the arbuscular mycorrhizal symbiosis. BMC Plant Biology 9: 10.

Govindarajulu M, PfeVer PE, Hairu J, Abubaker J, Douds DD, Allen JW, Bücking H, Lammers PJ, Shachar-Hill Y. 2005. Nitrogen transfer in the arbuscular mycorrhizal symbiosis. Nature 435: 819-823.

Grabherr MG, Haas BJ, Yassour M, Levin JZ, Thompson DA, Amit I, Adiconis X, Fan L, Raychowdhury R, Zeng Q et al. 2011. Full-length transcriptome assembly from RNA-seq data without a reference genome. Nature Biotechnology 29: 644-652.

Guether M, Neuhauser B, Balestrini R, Dynowski M, Ludewig U, Bonfante P. 2009. A mycorrhizal-specific ammonium transporter from Lotus japonicus acquires nitrogen released by arbuscular mycorrhizal fungi. Plant Physiology 150: 73-83.

Guether M, Volpe V, Balestrini R, Requena N, Wipf N, Bonfante P. 2011. LjLHT1.2 a mycorrhiza-inducible plant amino acid transporter from Lotus japonicus. Biology and Fertility of Soils 47: 925-936.

Guidot A, Verner MC, Debaud JC, Marmeisse R. 2005. Intraspecific variation in use of different organic nitrogen sources by the ectomycorrhizal fungus Hebeloma cylindrosporum. Mycorrhiza 15: 167-177.

Hadley G, Ong H. 1978. Nutritional requirements of orchid endophytes. New Phytologist 81: 561-569.

Hawkins HJ, Johansen A, George E. 2000. Uptake and transport of organic and inorganic nitrogen by arbuscular mycorrhizal fungi. Plant and Soil 226: 275285.

Hirner A, Ladwig F, Stransky H, Okumoto S, Keinath M, Harms A, Frommer W, Koch W. 2006. Arabidopsis LHT1 is a high-affinity transporter for cellular amino acid uptake in both root epidermis and leaf mesophyll. Plant Cell 18: 1931-1946.

Hynson NA, Madsen TP, Selosse M-A, Adam IKU, Ogura-Tsujita Y, Roy M, Gebauer G. 2013. The physiological ecology of mycoheterotrophy. In: Merckx VSFT, ed. Mycoheterotrophy: the biology of plants living on fungi. New York, NY, USA: Springer, 297-344.

Jacquemyn H, Honnay O, Cammue BPA, Brys R, Lievens B. 2010. Low specificity and nested subset structure characterize mycorrhizal associations in five closely-related species of the genus Orchis. Molecular Ecology 19: 40864095.

Jargeat P, Rekangalt D, Verner MC, Gay G, Debaud JC, Marmeisse R, Fraissinet-Tachet L. 2003. Characterisation and expression analysis of a nitrate transporter and nitrite reductase genes, two members of a gene cluster for nitrate assimilation from the symbiotic basidiomycete Hebeloma cylindrosporum. Current Genetics 43: 199-205.

Javelle A, Rodriguez-Pastrana BR, Jacob C, Botton B, Brun A, Andrè B, Marini AM, Chalot M. 2001. Molecular characterization of two ammonium transporters from the ectomycorrhizal fungus Hebeloma cylindrosporum. FEBS Letters 505: 393-398.

Kaldorf M, Schmelzer E, Bothe H. 1998. Expression of maize and fungal nitrate reductase genes in arbuscular mycorrhiza. Molecular Plant-Microbe Interactions 11: 439-448.

Kemppainen MJ, Pardo AG. 2011. Transformation of the mycorrhizal fungus Laccaria bicolor by using Agrobacterium tumefaciens. Bioengineered Bugs 2: 38-44.

Kiers ET, Duhame M, Beesetty Y, Mensah JA, Franken O, Verbruggen E, Fellbaum CR, Kowalchuk GA, Hart MM, Bago A et al. 2011. Reciprocal rewards stabilize cooperation in the mycorrhizal symbiosis. Science 333: 880882.

Kobae Y, Tamura Y, Takai S, Banba M, Hata S. 2010. Localized expression of arbuscular mycorrhiza-inducible ammonium transporters in soybean. Plant \& Cell Physiology 51: 1411-1415.

Koegel S, Ait Lahmidi N, Arnould C, Chatagnier O, Walder F, Ineichen K, Boller T, Wipf D, Wiemken A, Courty PE. 2013. The family of ammonium transporters (AMT) in Sorghum bicolor: two AMT members are induced locally, but not systemically in roots colonized by arbuscular mycorrhizal fungi. New Phytologist 198: 853-865.

Koegel S, Brulé D, Wiemken A, Boller T, Courty PE. 2015. The effect of different nitrogen sources on the symbiotic interaction between Sorghum bicolor and Glomus intraradices: expression of plant and fungal genes involved in nitrogen assimilation. Soil Biology and Biochemistry 86: 156-163.

Kohler A, Kuo A, Nagy LG, Morin E, Barry KW, Buscot F, Canbäck B, Choi C, Cichocki N, Clum A et al. 2015. Convergent losses of decay mechanisms and rapid turnover of symbiosis genes in mycorrhizal mutualists. Nature Genetics 47: 410-415.

Kuga Y, Sakamoto N, Yurimoto H. 2014. Stable isotope cellular imaging reveals that both live and degenerating fungal pelotons transfer carbon and nitrogen to orchid protocorms. New Phytologist 202: 594-605.

Kumar S, Stecher G, Tamura K. 2016. MEGA7: Molecular Evolutionary Genetics Analysis version 7.0 for bigger datasets. Molecular Biology and Evolution 33: 1870-1874.

Leake JR. 2004. Myco-heterotroph/epiparasitic plant interactions with ectomycorrhizal and arbuscular mycorrhizal fungi. Current Opinion in Plant Biology 7: 422-428.

López-Pedrosa A, González-Guerrero M, Valderas A, Azcón-Aguilar C, Ferrol N. 2006. GintAMT1 encodes a functional high-affinity ammonium transporter that is expressed in the extraradical mycelium of Glomus intraradices. Fungal Genetics and Biology 43: 102-110.

Lubkowitz M. 2011. The oligopeptide transporters: a small gene family with a diverse group of substrates and functions? Molecular Plant 4: 407-415.

Marini AM, Soussi-Boudekou S, Vissers S, Andre B. 1997. A family of ammonium transporters in Saccharomyces cerevisiae. Molecular and Cellular Biology 17: 4282-4293.

Martin F, Perotto S, Bonfante P. 2007. Mycorrhizal fungi: a fungal community at the interface between soil and roots. In: Pinton R, Varanini Z, Nannipieri P, eds. The Rhizosphere: biochemistry and organic substances at the plant-soil interface. Boca Raton, FL, USA: CRC Press, 201-236.

Minet M, Dufour ME, Lacroue F. 1992. Complementation of Saccharomyces cerevisiae auxotrophic mutants by Arabidopsis thaliana cDNAs. Plant Journal 2: 417-422.

Montanini B, Moretto N, Soragni E, Percudani R, Ottonello S. 2002. A highaffinity ammonium transporter from the mycorrhizal ascomycete Tuber borchii. Fungal Genetics and Biology 36: 22-34.

Montanini B, Viscomi AR, Bolchi A, Martin Y, Siverio JM, Balestrini R, Bonfante P, Ottonello S. 2006. Functional properties and differential mode of regulation of the nitrate transporter from a plant symbiotic ascomycete. Biochemical Journal 394: 125-134.

Morel M, Jacob C, Kohler A, Johansson T, Martin F, Chalot M, Brun A. 2005. Identification of genes differentially expressed in extraradical mycelium and ectomycorrhizal roots during Paxillus involutus-Betula pendula ectomycorrhizal symbiosis. Applied and Environmental Microbiology 71: 382-391.

Müller T, Avolio M, Olivi M, Benjdia M, Rikirsch E, Kasaras A, Fitz M, Chalot M, Wipf D. 2007. Nitrogen transport in the ectomycorrhiza association: the Hebeloma cylindrosporum-Pinus pinaster model. Phytochemistry 68: 41-51.

Nehls U, Kleber R, Wiese J, Hampp R. 1999. Isolation and characterization of a general amino acid permease from the ectomycorrhizal fungus Amanita muscaria. New Phytologist 142: 331-341.

Nurfadilah S, Swarts ND, Dixon KW, Lambers H, Merritt DJ. 2013. Variation in nutrient-acquisition patterns by mycorrhizal fungi of rare and common orchids explains diversification in a global biodiversity hotspot. Annals of Botany 111: 1233-1241.

Otero JT, Ackerman JD, Bayman P. 2004. Differences in mycorrhizal preferences between two tropical orchids. Molecular Ecology 13: 2393-2404.

Pérez-Tienda J, Testillano PS, Balestrini R, Fiorilli V, Azcón-Aguilar C, Ferrol N. 2011. GintAMT2, a new member of the ammonium transporter family in the arbuscular mycorrhizal fungus Glomus intraradices. Fungal Genetics and Biology 48: 1044-1055.

Perotto S, Benetti A, Sillo F, Ercole E, Rodda M, Girlanda M, Balestrini R. 2014. Gene expression in mycorrhizal orchid protocorms suggests a friendly plant-fungus relationship. Planta 239: 1337-1349.

Perrone I, Gambino G, Chitarra W, Vitali M, Pagliarani C, Riccomagno N, Balestrini R, Kaldenhoff R, Uehlein N, Gribaudo I et al. 2012. The grapevine root-specific aquaporin VvPIP2;4 N controls root hydraulic conductance and leaf gas exchange upon irrigation but not under water stress. Plant Physiology 160: 965-977. 
Peterson RL, Bonfante P, Faccio A, Uetake Y. 1996. The interface between fungal hyphae and orchid protocorm cells. Canadian Journal of Botany 74 : $1861-1870$.

Plassard C, Bonafosi B, Touraine B. 2000. Differential effects of mineral and organic $\mathrm{N}$ sources, and of ectomycorrhizal infection by Hebeloma cylindrosporum, on growth and $\mathrm{N}$ utilization in Pinus pinaster. Plant, Cell \& Environment 23: 1195-1205.

Rasmussen HN. 1995. Terrestrial orchids from seed to mycotrophic plant. Cambridge, UK: Cambridge University Press.

Schumann U, Smith NA, Wang MB. 2013. A fast and efficient method for preparation of high-quality RNA from fungal mycelia. BMC Research Notes 6: 71.

Selosse MA, Martos F. 2014. Do chlorophyllous orchids heterotrophically use mycorrhizal fungal carbon? Trends in Plant Science 19: 683-685.

Selosse MA, Rousset F. 2011. The plant-fungal marketplace. Science 333: 828829.

Selosse MA, Roy M. 2009. Green plants that feed on fungi: facts and questions about mixotrophy. Trends in Plant Science 14: 64-70.

Shah F, Rineau F, Canbäck G, Johansson T, Tunlid A. 2013. The molecular components of the extracellular protein-degradation pathways of the ectomycorrhizal fungus Paxillus involutus. New Phytologist 200: 875-887.

Smith SE, Read DJ. 2008. Mycorrhizal symbiosis. Cambridge, UK: Academic Press.

Stöckel M, Těšitelová T, Jersáková J, Bidartondo MI, Gebauer G. 2014. Carbon and nitrogen gain during the growth of orchid seedlings in nature. New Phytologist 202: 606-615.

Taylor DL, Bruns TD, Leake JR, Read DJ. 2002. Mycorrhizal specificity and function in myco-heterotrophic plants. In: van der Heijden MGA, Sanders IR, eds. Mycorrhizal ecology. Berlin, Germany: Springer-Verlag, 375-413.

Tian C, Kasiborski B, Koul R, Lammers PJ, Bucking H, Shachar-Hill Y. 2010. Regulation of the nitrogen transfer pathway in the arbuscular mycorrhizal symbiosis: gene characterization and the coordination of expression with nitrogen flux. Plant Physiology 153: 1175-1187.

Van Waes JM, Deberg PC. 1986. In vitro germination of some Western European orchids. Physiologia Plantarum 67: 253-261.

Vitousek PM, Howarth RW. 1991. Nitrogen limitation on land and in the sea: how can it occur? Biogeochemistry 13: 87-115.

Waterman RJ, Bidartondo MI, Stofberg J, Combs JK, Gebauer G, Savolainen V, Barraclough TG, Pauw A. 2011. The effects of above- and belowground mutualisms on orchid speciation and coexistence. American Naturalist 177: E54-E68.

Weiß M, Selosse MA, Rexer MI, Urban A, Oberwinkler F. 2004. Sebacinales: a hitherto overlooked cosm of heterobasidiomycetes with a broad mycorrhizal potential. Mycological Research 180: 1003-1010.
Willmann A, Weiss M, Nehls U. 2007. Ectomycorrhiza-mediated repression of the high-affinity ammonium importer gene AmAMT2 in Amanita muscaria. Current Genetics 51: 71-78.

Wipf D, Benjdia M, Tegeder M, Frommer WB. 2002. Characterization of a general amino acid permease from Hebeloma cylindrosporum. FEBS Letters 528 : 119-124.

Wright DP, Johansson T, Le Quéré A, Söderström B, Tunlid A. 2005. Spatial patterns of gene expression in the extramatrical mycelium and mycorrhizal root tips formed by the ectomycorrhizal fungus Paxillus involutus in association with birch (Betula pendula) seedlings in soil microcosms. New Phytologist 167: 579596.

Zhao X, Zhang J, Chen C, Yang J, Zhu H, Liu M, Lv F. 2014. Deep sequencing-based comparative transcriptional profiles of Cymbidium hybridum roots in response to mycorrhizal and non-mycorrhizal beneficial fungi. $B M C$ Genomics 15: 747.

\section{Supporting Information}

Additional Supporting Information may be found online in the Supporting Information tab for this article:

Fig. S1 Experimental set-up of the two RNA-Seq experiments.

Fig. S2 RT-PCR experiments on LMD samples using primers for housekeeping genes.

Fig. S3 RT-PCR analysis of Tulasnella calospora genes in LMD cell-type populations.

Fig. S4 Phylogenetic tree of plant ammonium transporters.

Table S1 List of primers used in this study

Please note: Wiley Blackwell are not responsible for the content or functionality of any Supporting Information supplied by the authors. Any queries (other than missing material) should be directed to the New Phytologist Central Office.

\section{About New Phytologist}

- New Phytologist is an electronic (online-only) journal owned by the New Phytologist Trust, a not-for-profit organization dedicated to the promotion of plant science, facilitating projects from symposia to free access for our Tansley reviews.

- Regular papers, Letters, Research reviews, Rapid reports and both Modelling/Theory and Methods papers are encouraged. We are committed to rapid processing, from online submission through to publication 'as ready' via Early View - our average time to decision is $<28$ days. There are no page or colour charges and a PDF version will be provided for each article.

- The journal is available online at Wiley Online Library. Visit www.newphytologist.com to search the articles and register for table of contents email alerts.

- If you have any questions, do get in touch with Central Office (np-centraloffice@lancaster.ac.uk) or, if it is more convenient, our USA Office (np-usaoffice@lancaster.ac.uk)

- For submission instructions, subscription and all the latest information visit www.newphytologist.com

See also the Commentary on this article by Dearnaley \& Cameron, 213: 10-12. 